\title{
Etnički sastav naselja Boke Kotorske prema popisu stanovništva iz 1900. godine
}

DOI: https://doi.org/10.11567/met.35.3.1 UDK: 323.11:351.755.3(497.16-3Boka Kotorska)"1900" Izvorni znanstveni rad Primljeno: 09.12.2019. Prihvaćeno: 07.03.2020.

\author{
Saša Mrduljaš \\ Institut društvenih znanosti Ivo Pilar - Područni centar Split, Split \\ Sasa.Mrduljas@pilar.hr
}

\begin{abstract}
SAŽETAK
Složena vjerska i etnička slika Boke Kotorske stvorena je prije nekih sedam stotina godina i do danas se nastavila mijenjati. No relativno pouzdane informacije o etničko-brojčanim suodnosima dobivamo tek od vremena Druge austrijske uprave (1814. - 1918.), tijekom koje se Boka Kotorska nalazi u okvirima Kraljevine Dalmacije. Pritom su od posebne važnosti suvremeni popisi stanovništva provedeni 1857., 1869., 1880., 1890., 1900. i 1910. Ti popisi nisu registrirali etničku pripadnost, već vjersku, a od 1880. i jezičnu. Stoga se do pokazatelja o etničkom sastavu Boke može doći samo kombinacijom tih podataka. Unatoč tome što popisi iz 1880. i 1890. dopuštaju taj tip kalkulacija, ipak su neprikladni za stjecanje cjelovite slike, prvenstveno stoga što su kod njih ukupnoj populaciji pridodavani brojni vojnici stacionirani na bokeljskom prostoru, i to bez mogućnosti da ih se u cilju uvida u narodnosni karakter Boke izdvoji iz stvarne mase stanovništva. Od popisa iz 1900. takvo je izuzimanje moguće. Dakle tek su njime stvorene pretpostavke da se posrednim proračunima, što će biti predmetom ovoga rada, utvrde brojčani suodnosi različitih etničkih zajednica na tlu Boke Kotorske, i to do razine svih njenih naselja.
\end{abstract}

KLJUČNE RIJEČI: Boka Kotorska, popis stanovništva, katoličanstvo, pravoslavlje, Hrvati, Srbi, Crnogorci

\section{UVOD: POVIJESNI OKVIR}

Postojeća te u znatnoj mjeri heterogena vjerska i etnička slika Crne Gore rezultat je dubokih transformacija koje su se proteklih tisuću godina zbile unutar prostora koji zauzima. ${ }^{1}$ Ranosrednjovjekovna kneževina Duklja, sa svojom okosnicom na suvremenome crnogorskom tlu, bila je u vrijeme i nakon crkvenog raskola iz 1054. u katoličkoj sferi, jednako kao susjedna joj Travunija te Zahumlje, koji su se znatnim dijelom 11. i 12. stoljeća nala-

1 Ovaj rad nastao je u okviru znanstvenoistraživačkog projekta Povijesno oblikovanje etničkih identiteta na tlu južne Dalmacije, istočne Hercegovine i Crne Gore (Znanstveno-istraživački projekti Instituta društvenih znanosti Ivo Pilar /2019./2020./). 
zili pod dukljanskom vlašću. Ulogu vjerskog središta tadašnje dukljanske kneževine, a poslije kraljevine, imala je Barska metropolija. Ujedno je bila političkim osloncem dinastije Vojislavljevića (Peričić, 1991).

Krajem 12. stoljeća nekadašnja Duklja, Travunija i Zahumlje potpadaju pod vlast Srbije, čija pravoslavna crkvena organizacija 1219. stječe samostalan status. Riječ će biti o Žičkoj, odnosno Pećkoj arhiepiskopiji, naknadno patrijaršiji, koja će pak predstavljati politički oslonac srpskoj dinastiji Nemanjića. Budući da je posrijedi vrijeme oštre polarizacije između katoličanstva i pravoslavlja, pod srpskom je vlašću dukljansko-zahumski živalj gotovo $\mathrm{u}$ potpunosti preveden $\mathrm{u}$ pravoslavlje. Znatnija iznimka bili su primorski gradovi, kojima je iz praktičnih razloga dopušteno očuvanje autonomnog statusa, a time i zadržavanje katolicizma. Pod utjecajem Dubrovačke Republike, Hrvatske, Bosne i franjevačkog reda do djelomične obnove katolicizma doći će u zapadnijim dijelovima nekadašnjeg Zahumlja te u pojedinim, primorskim krajevima Travunije. No među slavenskom populacijom današnje Crne Gore trajno će opstati samo u priobalnim središtima i dijelu naselja koja im gravitiraju (Čorović, 1995: 148-149, 158; Đurović, 1970: 18; Živković, 1989: 163).

Nakon dezintegracije srpske države, uvelike potaknute osmanskim prodorima na Balkan, te razdoblja izmjene različitih državnih vlasti, primorski krajevi Crne Gore, većinom tijekom prve polovine 15. stoljeća, dospijevaju pod Mletačku Republiku. Daljnja osmanska osvajanja mletačke će posjede u primorju svesti na usitnjene, međusobno odvojene enklave unutar kojih će se nastaviti u osnovi uzorna katoličko-pravoslavna koegzistencija (Luković, 1951: 15-17). Na ostatku primorja, trpeći daljnje gubitke, ovaj put pod Osmanlijama, katoličanstvo se među slavenskom populacijom održalo samo kod manjeg dijela stanovnika okolice Bara (Marković, 1902; Živković, 1992: 102-104).

Pod osmanskim utjecajem zbit će se daljnje promjene na vjerskoj i etničkoj slici Crne Gore. Albansko prodiranje u pojedine granične krajeve, primjetno već krajem srednjeg vijeka, definitivno će utvrditi albansku dominaciju u njima. Nadalje, masovna islamizacija albanskoga katoličkog življa potaknut će slične procese u slavenskom susjedstvu. Crna Gora sa susjednom Hercegovinom, ali i sjevernom Albanijom, postat će demografskim spremnikom iz kojeg će poteći masovne seobe prema susjednim, ratovima depopuliziranim prostorima, između ostaloga i prema današnjem Sandžaku, u koji će se kontinuirano doseljavati crnogorski pravoslavni i muslimanski živalj. Ipak, najdalekosežnija pojava bit će formiranje podlovćenske Crne Gore, koja će 
stjecanjem državnoga kapaciteta te širenjem proizvesti poseban oblik samosvijesti kod svoje pravoslavne populacije (Bojović, 1991; Čulinović, 1981; Folić, 2013; Lutovac, 1978; Zefi, 2003).

Procesi etničke diferencijacije slavenskog življa Crne Gore bili su usko povezani s onom vjerskom. Katolici su, što je dodatno poticano prvo prevlašću pravoslavlja, a zatim islama, bili čvrsto usmjereni prema Zapadu. Ta je usmjerenost, uz ostalo, vodila društveno-kulturnoj integraciji u širu narodnosnu cjelinu njihova jezika i vjere, koja tijekom nacionalno-formativnih procesa postaje prepoznatljiva po hrvatskom imenu. Budući da je samosvojno postojanje ovdašnjeg pravoslavlja »otpočetka « bilo povezano s ciljevima srpske dinastije, a sukladno tome i države, kod crnogorskih su se pravoslavaca zarana oblikovali određeni oblici srpske protonacionalne svijesti. S vremenom će dobiti konkurenciju u crnogorskoj narodnosnodržavnoj ideji, čime će biti uzrokovan svojevrstan lom u identitetnoj sferi crnogorskoga pravoslavnoga korpusa, koji još uvijek sprečava njegovu konačnu nacionalnu definiciju. Slavensko muslimansko stanovništvo u Crnoj Gori povijesno je, kao nositelj osmansko-islamske državne koncepcije, bilo snažno distancirano od istojezičnih kršćanskih zemljaka. Istovremeno, poistovjećivalo se s ostatkom ovdašnjega slavenskog muslimanskog življa, najsnažnije koncentriranog u Bosni, što je naposljetku omogućilo njegovo suživljavanje s bošnjačkom nacionalnom konstrukcijom (Andrijašević, 2004; Banac, 1988; Ičević, 2015).

S obzirom na izrazitu složenost vjerske i etničke slike Crne Gore te procesa kojima je oblikovana očekivano je da njena pojavnost otvara čitav niz bitnih istraživačkih pitanja. Ovdje se usredotočujemo na jedno od njih. Naime gotovo cjelokupan prostor slavenskoga, katoličkog (hrvatskog) i pravoslavnog (srpskog/crnogorskog) isprepletanja nalazio se u dijelu crnogorskog primorja koji se za mletačke vlasti obranio od osmanskih navala (istočna Boka, grad Budva i Paštrovići), odnosno onom koji je krajem 17. i početkom 18. stoljeća oslobođen od Osmanlija (Krivošije, zapadna Boka, Grbalj te Pobori, Maine i Brajići u okolici Budve). Tijekom naknadne, Druge austrijske uprave (1814. - 1918.), kada se navedeni krajevi nalaze u okvirima Kraljevine Dalmacije, pridodan im je 1878. i Spič, tj. dio osmanske katoličko-pravoslavne zone zapadno od Bara (Obad, 2010: 5).

Unatoč stoljetnome katoličko-pravoslavnom isprepletanju na tlu Boke Kotorske, prve sveobuhvatne podatke iz kojih se odgovarajućim analizama može steći uvid o brojčanom karakteru vjersko-etničkih suodnosa dobivamo iz austrijskih popisa provedenih od druge polovine 19. stoljeća. No sve 
do kraja tog stoljeća ti popisi ne dopuštaju stjecanje preciznije slike o narodnosnim značajkama Boke Kotorske i (velikog dijela) njenih naselja. Prvi koji takvo što uvelike omogućuje jest popis iz 1900. godine. Stoga ćemo u ovom radu, koristeći se analizom podataka koje pruža taj popis, pokušati utvrditi kakvi su u brojčanom smislu bili etnički suodnosi na tlu Boke Kotorske, njenih upravnih jedinica te samih naselja (vidjeti karte u Prilogu 1 i 2) u vremenu za kojeg je stoljetna vlast, uvjetno rečeno katoličkih država nad Bokom bila u svom zalazu te također u vremenu koje prethodi političkim promjenama i modernizacijskim procesima u sklopu kojih će njena etnička slika, registrirana na samom početku prošlog stoljeća, biti iz korijena izmijenjena.

\section{METODOLOŠKI PRISTUP}

U upravnom smislu, aktualnom tijekom popisa iz 1900., Kraljevina Dalmacija je bila podijeljena na »kotarska satništva« koja su uključivala »sudbene kotare«, podijeljene, u većini slučajeva, na »političke općine«. One su najčešće uključivale više »poreznih općina « formiranih od pojedinačnog naselja ili, u rjeđim slučajevima, od više (manjih) naselja. U nastavku rada, zbog razumljivosti te sukladno dosadašnjoj praksi, upotrebljavamo sljedeće nazive: »kotar« (»kotarsko satništvo«), »sudbeni okrug«/»okrug« (»sudbeni kotar«), »općina« (»politička općina«) i »naselje« (»porezna općina«) (Crkvenčić i Schaller, 2005: 113, 116, 2006: 57, 2007: 68-69).

Dio današnjega crnogorskog primorja koji je bio dijelom Kraljevine Dalmacije upravno je potpadao pod kotar Kotor $\left(673,79 \mathrm{~km}^{2}\right)$, koji je bio podijeljen na četiri okruga: Budva $(155,07$ km²), Herceg-Novi $(132,56$ km²), Kotor $\left(194,42 \mathrm{~km}^{2}\right)$ i Risan $\left(191,74 \mathrm{~km}^{2}\right)$. Pritom se budvanski okrug sastojao od općina Budva (51,37 km²), Paštrovići $\left(65,33 \mathrm{~km}^{2}\right)$ i Spič $\left(38,37 \mathrm{~km}^{2}\right)$; hercegnovski od općina Herceg-Novi $\left(94,15 \mathrm{~km}^{2}\right)$ i Luštica $\left(38,41 \mathrm{~km}^{2}\right)$; kotorski od općina Kotor $\left(51,95 \mathrm{~km}^{2}\right)$, Dobrota $\left(8,49 \mathrm{~km}^{2}\right)$, Krtole $\left(21,7 \mathrm{~km}^{2}\right)$, Lastva $\left(6,7 \mathrm{~km}^{2}\right)$, Muo $\left(1,89 \mathrm{~km}^{2}\right)$, Prčanj $\left(3,84 \mathrm{~km}^{2}\right)$, Stoliv $\left(3,31 \mathrm{~km}^{2}\right)$, Tivat $(4,84$ $\left.\mathrm{km}^{2}\right)$ i Grbalj $\left(91,7 \mathrm{~km}^{2}\right)$; risanski od općina Perast $\left(11,96 \mathrm{~km}^{2}\right)$ i Risan $(179,78$ $\mathrm{km}^{2}$ ) (Special-Orts-Repertorium..., 1894: 16-41). Većina općina sastojala se od niza naselja. Iznimka su bile male općine kotorskog okruga koje su imale jedno ili dva naselja (Dobrota, Lastva /2/, Muo, Prčanj, Stoliv /2/ i Tivat).

Za ukupnost prostora koji je zauzimao kotar Kotor nerijetko se upotrebljava naziv Boka Kotorska sukladno okosnici koju je imao u istoimenom zaljevu. No tako se može shvatiti samo u širem smislu. U užemu Boku Kotorsku 
čine primorska mjesta zaljeva te ona koja nisu na samoj obali, ali su egzistencijalno upućena na bokeljsko primorje te se kao takva identificiraju s Bokom. Sve ostale cjeline kotara Kotor ostvarivale su svoju dostatnost, pa i prepoznatljivost, i izvan užega bokokotorskog okvira. Među njih spadaju sjeverozapadni dijelovi općina Herceg-Novi i Risan smješteni u planinskom masivu Orjena i nastanjeni plemenom Krivošija te svi krajevi jugoistočno od Kotora koji su, između ostaloga, u doticaju s otvorenim morem. To su Grblje, no bez naselja Lješevići, koje je sve do druge polovine 19. stoljeća povezano s Krtolama, grad Budva, niz mjesta oko nje koja su bila raspoređena unutar triju povijesnih zajednica, tj. Pobora, Maina i Brajića, te Paštrovići i Spič, uvelike orijentiran prema susjednom Baru.

Suvremeni popisi stanovništva u Kraljevini Dalmaciji počinju se provoditi u drugoj polovini 19. stoljeća. Za austrijske vlasti bilo ih je šest i provedeni su 1857., 1869., 1880., 1890., 1900. i 1910. Prvi među njima metodološki se razlikovao od ostalih. Njime se popisivalo po principu stalnog boravišta neovisno o tome je li se u trenutku popisivanja i boravilo u njemu. Nasuprot tome, u naknadnim popisima bilježeno je prisutno stanovništvo neovisno o mjestu stalnog boravka. Nijedan od austrijskih popisa nije uključivao pitanja o etničkoj pripadnosti. Do takvih podataka može se doći samo kombinacijom podataka o vjeri i jeziku popisanog stanovništva. Prva dva popisa ne dopuštaju tu vrstu kombinatorike jer ne pružaju podatke o jezičnoj identifikaciji stanovništva (Bralić i Ramljak, 2010: 292-293). Popisi iz 1880. i 1890. znatno su iskoristiviji, ali niti oni ne omogućavaju stjecanje, uvjetno rečeno, preciznije slike o narodnosnom sastavu Boke Kotorske.

Naime u nizu bokeljskih mjesta bila je stacionirana vojska. U kontekstu takvih naselja registriran je broj vojnika smještenih u njima, no oni u popisnim kategorijama nisu navođeni posebno u odnosu na ostalo stanovništvo, već zajedno sa njim. Primjerice, po popisu iz 1890., za Kotor je navedeno da je u njemu stacionirano 1035 vojnika, ali nemamo podatke o njihovoj vjerskoj i jezičnoj pripadnosti. Oduzimanjem tog iznosa od broja svih onih koji su popisani u Kotoru (3329) može se doći do stvarnog broja stanovništva tog grada (2294), no ne i do uvida u njegovu vjersku i etničku strukturu. Zbog tog nerješivog problema nije moguće utvrditi etnički karakter za čitav niz mjesta u kojima je bila locirana vojska, a samim tim ni za Boku Kotorsku u cjelini. Iako vojnika nije bilo mnogo, svega par tisuća, bilo ih je dovoljno da poremete uvid u etnički sastav ne toliko brojnog stanovništva Boke.

Od popisa iz 1900. omogućeno je nadilaženje spomenutog problema jer su u njemu vojnici, kojih je tada bilo 2981, razvrstani po svim kategorijama 
(Crkvenčić i Schaller, 2006: 56). Primjerice te je godine u Kotoru 747 vojnika, od čega 424 katolika, 281 pravoslavca i 42 pripadnika drugih vjera; 160 vojnika govorilo je njemački, 47 »srbsko-hrvatski«itd. Ti podaci dopuštaju izuzimanje vojnika po svim popisnim kategorijama iz ukupnosti stanovništva naselja, općina, okruga i na koncu samoga kotara. Time se napokon, u osnovi prvi put u povijesti, omogućava stjecanje uvida u stvarne etničkobrojčane suodnose između 34.115 »civilnih« stanovnika Boke.

No i popis iz 1900. zadržao je jednu manjkavost koja umanjuje njegovu preciznost. Sukladno dotadašnjoj praksi, i kod njega je ukupno stanovništvo bilo razvrstano po spolu i po vjeri. Ali podaci o uporabnom jeziku, koji se svode na izjašnjavanje u korist »srbsko-hrvatskog «, njemačkog, talijanskog i »drugih jezika«, uzimani su samo za domaće stanovništvo. Pritom se pod tim stanovništvom podrazumijevalo austrijske državljane Monarhije, što je precizirano u idućem popisu (Bralić i Ramljak, 2010: 293, 311; Makale, 1912: 43, 76-77). Za »ostalo« stanovništvo, ono bez austrijskog državljanstva, tj. s drugim državljanstvom, nije evidentirana jezična pripadnost. U toj skupini nalazili su se i državljani ugarskog dijela Monarhije, što se vidi i iz toga što je među vojnicima, koji su morali pripadati austrougarskom državnom okviru, bilo 952 ili 32\% onih kojima nije evidentirana jezična identifikacija. Osim ugarskih državljana među »ostalima« su se nalazile i osobe iz $\mathrm{BiH}$, Crne Gore itd. Ako izuzmemo gore navedeni broj vojnika (952), toj je grupaciji 1900. pripadalo 2455 osoba. Ono što je sigurno jest da je riječ bila o doseljenicima ili njihovim potomcima, pri čemu je nemoguće točno utvrditi odakle su poticali te koje su vjere i jezika bili. Na temelju ovdje provedenog istraživanja može se s visokom dozom sigurnosti ustvrditi da se ponajviše radilo o pravoslavnim Crnogorcima koji su u povijesnom kontinuitetu pristizali iz zaleđa u priobalje.

Kako bismo utvrdili etnički sastav pojedinih naselja, općina, okruga, pa u konačnici samoga kotara Kotor, u radu smo se poslužili sljedećim pristupom. Kako je naznačeno, prvo smo iz ukupnog stanovništva po svim popisnim kategorijama isključili vojnike. Time je dobiven stvarni broj prisutnog stanovništva, i to po svim popisnim razinama. Do broja Srba/Crnogoraca došli smo tako da smo prihvatili, barem uvjetno, da je identičan broju pravoslavnih vjernika, kojih je 1900. bilo 23.746. Među njima je morao biti jedan manji broj pravoslavaca druge etničke pripadnosti, npr. Ukrajinaca, Rumunja itd. No budući da nema mehanizma kojim bi se utvrdio broj takvih doseljenika, što bi omogućilo njihovo izuzimanje, najmanje će se pogriješiti ako se sve pravoslavce računa kao Srbe/Crnogorce. Prvi jugoslavenski po- 
pis, onaj iz 1921., koji je bio znatno opsežniji na razini jezičnih odrednica, na prostoru (nekadašnjega) kotara Kotor registrirao je svega 140 Rusa, od kojih je zasigurno velika većina pristigla iza Oktobarske revolucije 1917., te devet Rumunja (Definitioni rezultati..., 1932). Premda je dvadesetak godina prije situacija bila drugačija, teško je pretpostaviti da je tada u Boki Kotorskoj bilo mnogo više nesrpskog/necrnogorskog pravoslavnog življa. Ujedno, valja naglasiti da broj pravoslavaca uključuje one s austrijskim i one sa kojim drugim državljanstvom.

Do broja Hrvata došli smo tako da smo od ukupnog broja katolika, kojih je na razini kotara Kotor bilo 10.321, te pripadnika »drugih vjera «, kojih je bilo tek 48, odbili broj govornika njemačkog (116), talijanskog (601) i drugih jezika (87), uz pretpostavku da su tim izuzimanjem, osim govornika navedenih jezičnih grupacija, izuzeti i pripadnici »drugih vjera« (govornici njemačkog i »drugih jezika« koji nisu bili katolici). Tako dobiveni broj, koji na razini cjelokupnoga kotara iznosi 9565, uvjetno bi odgovarao broju Hrvata. Unutar tog broja, kao i u slučaju Srba/Crnogoraca, morao je biti zastupljen i izvjestan broj prvenstveno ugarskih, etnički nehrvatskih državljana katoličke vjere. No i u ovom slučaju riječ je o relativno malom broju. Kao što je istaknuto, austrijskih državljana koji su se koristili jezicima koji na bokeljskom prostoru nisu bili povijesno ukorijenjeni, tj. njemačkim ili kojim od »drugih jezika«, bilo je malo - konkretno, svega 203 ili 0,6\% od ukupne populacije. Iz toga se može zaključiti da je općenito bilo malo doseljenika sa sjevera Monarhije, pa tako i iz njezina ugarskog dijela. Na koncu, po popisu iz 1921., na tlu (nekadašnjega) kotara Kotor bilo je svega 29 govornika mađarskog i 95 govornika »čehoslovačkog «, među kojima su se nalazili i Slovaci, koji su do 1918. bili dijelom ugarskoga državnog okvira (Definitioni rezultati..., 1932).

U izloženoj kombinatorici nismo se služili podacima u kontekstu »srbskohrvatskog «jezika. Za razliku od podataka o uporabi njemačkog, talijanskog i »drugih jezika« koji se odnose na malobrojan dio populacije, »srbsko-hrvatskim« je govorila velika većina bokeljskog stanovništva, a zasigurno i najveći dio doseljenika bez austrijskog državljanstva (kojima nije evidentirana jezična pripadnost). Stoga bi kombinacije sa »srbsko-hrvatskim« dovele do najvećeg odstupanja od stvarnog stanja. Ipak, u tablicama u nastavku rada nalazit će se i podaci o broju govornika tog jezika za svako naselje, općinu, okrug i sam kotar. Posredstvom tih podataka na razini niza naselja moguće je utvrditi etničku pripadnost doseljenih neaustrijskih državljana u cjelini ili u minimalnom broju. 
Konkretno, ako je u pojedinom vjerski homogenom naselju broj pravoslavaca, tj. Srba/Crnogoraca ili broj katoličkih Hrvata bio veći od broja govornika »srbsko-hrvatskog «, razlika između ta dva broja predstavlja stvarni broj pravoslavnih ili katoličkih doseljenika bez austrijskog državljanstva. Npr. u naselju Mišići u općini Spič živjelo je 140 stanovnika i svi su bili pravoslavne vjere. Od njih je austrijskih državljana bilo 133 i svi su govorili »srbsko-hrvatskim«. Stoga je izvjesno da je u navedenome mjestu svih sedam doseljenika, dakle osoba koji nisu imali austrijsko državljanstvo, bilo pravoslavne vjere.

$\mathrm{S}$ druge strane, $\mathrm{u}$ vjerski heterogenim naseljima u kojima je broj pravoslavaca, tj. Srba/Crnogoraca, ili broj katoličkih Hrvata bio veći od broja govornika »srbsko-hrvatskog « jezika moguće je utvrditi samo minimalni broj doseljenika pojedine vjere. Npr. u naselju Šušanj, također u općini Spič, živjela su 293 stanovnika, od čega 269 katolika i 24 pravoslavca. Među njima je austrijskih državljana bilo 260 i svi su govorili »srbskohrvatskim«, dok je osoba bez austrijskog državljanstva bilo 33. U ovom slučaju moguće je ustvrditi da je minimalni broj katolika među doseljenicima iznosio devet, s obzirom na to da je za toliko veći broj katolika od austrijskih državljana, odnosno govornika »srbsko-hrvatskog «. Mogao je biti i veći, no za ostale »neaustrijske« doseljenike jednostavno je nemoguće utvrditi kojim su vjerskim i jezičnim grupacijama pripadali.

Kod heterogenih naselja u kojima je broj pravoslavaca, tj. Srba/Crnogoraca, i katoličkih Hrvata bio manji od broja govornika »srbsko-hrvatskog « nije bilo moguće utvrditi vjersku, odnosno etničku pripadnost doseljenika bez austrijskog državljanstva. Npr. u naselju Đenđinovići unutar općine Spič živjelo je 206 stanovnika, od čega 134 katolika i 72 pravoslavca. Od njih je austrijskih državljana bilo 189 i svi su govorili »srbsko-hrvatskim«, dok je doseljenika bez austrijskog državljanstva bilo sedamnaest. U ovom slučaju ništa se ne može reći o vjerskoj i etničkoj pripadnosti tih doseljenika. Mogli su svi odreda biti katolici ili pravoslavci, iako je vjerojatnije da je među njima bilo i jednih i drugih, no u nepoznatim omjerima.

Na opisani smo način bili u prilici utvrditi da je od 2455 stranih državljana (osoba za koje nije navedena jezična pripadnost) najmanje njih 436 ili 17,8\% pripadalo Srbima/Crnogorcima te 30 ili 1,2\% Hrvatima. Potvrde o znatnome, moguće prevladavajućem udjelu Srba/Crnogoraca među doseljenicima bez austrijskog državljanstva mogle bi se dobiti i usporedbama između popisa. Primjerice, 1890. u naselju Kavač u općini Kotor bilo je 182 stanovnika, od čega 76 katolika i 106 pravoslavaca. Pritom je austrijskih državljana bilo 
171 i svi su govorili »srbsko-hrvatskim« (Special-Orts-Repertorium..., 1894). Dakle bilo je svega jedanaest doseljenika bez austrijskog državljanstva. Po popisu iz 1900., u Kavču živi 221 stanovnik, od čega 78 katolika i 143 pravoslavca. Pritom je austrijskih državljana bilo 184 i svi su govorili »srbsko-hrvatskim«. No sad je već 37 doseljenika bez austrijskog državljanstva. Ako se uzme u obzir da je u Kavču do 1900. godine došlo do uočljivog porasta broja pravoslavaca, tad je gotovo sigurno da je on uzrokovan doseljavanjima, $u$ osnovi iz Crne Gore. Da je to naselje bilo izloženo intenzivnom useljavanju Srba/Crnogoraca, i to neovisno o državljanstvu, svjedoči to što je 1857. među 185 njegovih stanovnika pravoslavnih vjernika bilo 95 ili 51,4\%, dok ih je četrdesetak godina poslije gotovo dvije trećine (Kozličić i Bralić, 2012: 234).

Razumljivo, dostupnim podacima i njihovom kombinatorikom ne može se utvrditi broj autohtonih bokeljskih Hrvata i Srba/Crnogoraca s jedne te broj doseljenih Hrvata i Srba/Crnogoraca, odnosno njihovih potomaka, s druge strane. Izvjesno je da je domaća populacija bila izrazito većinska u manjim, za useljavanje neprivlačnim mjestima. Izvjesno je i to da u veća središta pristižu doseljenici prvenstveno iz austrijskog dijela Monarhije, ponajviše oni iz ostatka Dalmacije. Iz tog smjera pristižu Hrvati i Srbi, a u manjoj mjeri i iz ugarskog dijela Monarhije. Pravoslavci iz Crne Gore, a zasigurno i iz istočne Hercegovine, naseljavaju se i u ta središta, ali i po manjim naseljima.

Doseljavanje Hrvata i Srba/Crnogoraca olakšavala je jezična istovrsnost s domaćim stanovništvom. Ono je bilo olakšano i doseljenicima koji su se koristili talijanskim jezikom s obzirom na to da je u Boki postojala stoljetna tradicija njegove upotrebe. S tim u vezi očekivano je da je u njoj obitavao određeni broj doseljenih Talijana, ali i to da se dio domaćeg, ponajprije katoličkog, realno hrvatskog i statusno istaknutijeg stanovništva, slično kao i u drugim dijelovima Dalmacije izjašnjavao u korist talijanskoga, tim više što austrijski popisi nisu bilježili očitovanje o materinskom, već o uporabnom jeziku. Da je takva izjašnjavanja moglo biti, sugeriralo bi primjerice to da je po popisu iz 1900. u kotaru Kotor bilo 611 govornika talijanskog, a po popisu iz 1921. svega 197 (Definitioni rezultati..., 1932). S druge strane, pitanje je koliko se katoličkih, etnički nehrvatskih doseljenika, prvo jezično, a zatim i općenito asimiliralo u hrvatsku identitetnu sferu do popisa iz 1900.

Osim okolnosti koje su poticanjem doseljavanja išle $u$ prilog brojčanom uvećavanju hrvatske i srpske/crnogorske zajednice postojale su i one koje su umanjivale brojčanu snagu domaćeg življa, prvenstveno putem znatnog iseljavanja s bokeljskog prostora. O tome, uz ostalo, svjedoči snažna 
disproporcija između muškaraca i žena u pojedinim mjestima. U stabilnim prilikama očekivano je da pripadnika obaju spolova ima podjednako, odnosno, izraženo u postocima, 50\% prema 50\%. Na razini Boke taj je omjer iznosio 53\%, a u pojedinim mjestima i preko $60 \%$ u korist žena. Ta snažna disproporcija posebice je uočljiva u bokeljskim, tradicionalno pomorskim mjestima, dakle i u glavnini onih koja su imala hrvatsku većinu, te $u$ iseljeništvu »sklonim « Paštrovićima i Spiču. U niže priloženim tablicama za svako je naselje naveden brojčani odnos muškaraca i žena, tako da je moguće sagledati omjer disproporcija kako na razini samih mjesta tako i u kontekstu njihove međusobne usporedbe. Iz tablice u Prilogu 3 koja se odnosi na vojnike izostavljena je ta popisna kategorija jer su svi vojnici bili muškarci. Sveukupno, kada se uzmu o obzir pozitivni i negativni trendovi koji su utjecali na brojčano pozicioniranje hrvatske i srpske/crnogorske zajednice, može se zaključiti da su one, barem u vremenu o kojem je riječ, uspijevale zadržati približno jednak suodnos.

Na temelju dostupnih podataka i njihove kombinatorike doći ćemo do relativno točnog uvida u etničko-brojčane suodnose na tlu Boke Kotorske početkom 20. stoljeća. Bitno je međutim istaknuti da se njen tadašnji upravnoteritorijalni okvir donekle izmijenio unutar Jugoslavije, ponajprije stoga što su u 1936./1937. Herceg-Novom, a time i Boki Kotorskoj, pridodane dvije katastarske općine trebinjskoga kotara, tj. Kruševice $\left(66,8 \mathrm{~km}^{2}\right)$ i Sutorina $\left(19,1 \mathrm{~km}^{2}\right)$. One su putem pripadnosti Herceg-Novom postale dijelom Crne Gore tijekom (poslije)ratne federalizacije jugoslavenske države. Pritom Kruševice, poput Krivošija, pripadaju planinskome masivu Orjena, dok je Sutorina sa svojim naseljima sastavni dio bokeljskog primorja, od kojeg zauzima 5,3 km obalne linije (Tuno i sur., 2011: 45, 53; Mulić, 2015; Spahić i sur., 2015). U priložene proračune nisu uvršteni podaci za spomenute općine. Njih ćemo prezentirati u Prilogu 4, i to za 1895. i 1910., kad su provedeni popisi u BiH, prilikom kojih su Kruševice i Sutorina zajedno imale 2099, odnosno 2318 stanovnika, gotovo odreda Srba/Crnogoraca.

U sklopu predodžbi o geografskom okviru Boke Kotorske valja imati u vidu da se najjužniji dio Konavala nalazi nasuprot poluotoku Luštici, tj. istočnom ulazu u Boku te južno od hercegnovskih naselja. Taj dio Konavala predstavlja svojevrsno, zapadno krilo ulaza u sam zaljev. Iako nije dijelio državnu ili upravnu »sudbinu« Boke, od koje je zadugo bio politički odvojen osmanskom, tj. bosansko-hercegovačkom Sutorinom, činjenica je da u geografskom smislu predstavlja i njen dio. Stoga u Prilogu 5 donosimo popisne podatke iz 1900. i za dva naselja koja se nalaze na tom dijelu Konava- 
la, tj. za Đuriniće i Vitaljinu. Kao i u slučaju Kruševica te Sutorine, podaci o tim naseljima, koja su 1900. godine brojila 808 stanovnika, gotovo isključivo Hrvata, nisu uvršteni u naše proračune, no njihova dostupnost omogućuje stjecanje potpunije slike o etničkim suodnosima u kontekstu Boke.

\section{ETNIČKA STRUKTURA KOTARA KOTOR}

U nastavku rada priložene su odgovarajuće tablice stanovništva razvrstanog po spolnim, jezičnim i etničkim kategorijama za cjelokupni kotar Kotor (tablica 5), sve njegove okruge, općine i naselja (tablice $1-4$ ). Iz njih su isključeni pripadnici vojske. Tablica s podacima koji se odnose na vojsku, na naselja u kojima je bilo vojnika te na njihovu podjelu po vjeri i jeziku dio je Priloga 3. Podaci koji se nalaze u tablicama prezentirani su sukladno metodi koju smo obrazložili te prema rezultatima dobivenim iz proračuna.

Kratice u tablicama znače sljedeće: »UK « = ukupni broj stanovništva; »M« $=$ muškarci; $» Z ̌$ « = žene; $» J E Z «=$ stanovništvo kojemu je popis utvrdio uporabni jezik (austrijski državljani); »SH«, »NJ《, » $\mathrm{T} « \mathrm{i} » \mathrm{OST}$ « = broj stanovništva koji je upotrebljavao »srbsko-hrvatski«, njemački, talijanski te koji od ostalih jezika (npr. slovenski, češki, poljski itd.) u sklopu onog dijela populacije kojoj je utvrđen uporabni jezik (austrijski državljani); »N-J $\mathrm{J}_{\text {= }}$ stanovništvo kojem prilikom popisa nije utvrđen uporabni jezik i koje nije imalo austrijsko državljanstvo (npr. porijeklom iz ugarskog dijela Monarhije, $\mathrm{BiH}$, Crne Gore itd.); »H«= Hrvati; »\%«= postotak Hrvata; »S/C «= Srbi/Crnogorci; »\%« = postotak Srba/Crnogoraca; »S/C+« = stvarni (etnički homogena naselja) ili minimalni broj (etnički heterogena naselja) doseljenih Srba/Crnogoraca koji nisu imali austrijsko državljanstvo. Vertikalno, pod odgovarajućim brojevima istaknuti su okruzi (npr. 1. okrug Budva), općine (npr. 1.1. općina Budva; 1.2. općina Paštrovići, 1.3. općina Spič) te naselja pojedinih općina (1, 2, 3 itd.).

S obzirom na cilj rada $u$ tablicama nije bilo potrebe, a ni mjesta, iznositi popisne podatke o pripadnosti pojedinim vjerama. Kao što je rečeno, ovdje smo prihvatili da broj pravoslavaca odgovara broju Srba/Crnogoraca, dok bi zbroj Hrvata te govornika njemačkog, talijanskog i drugih jezika odgovarao broju katolika i pripadnika drugih vjera. Kako je broj pripadnika drugih vjera bio neznatan (48) i kako ih zbog nedostatka prostora nije bilo moguće uvrstiti u tablice, ovdje ćemo navesti naselja u kojima ih je bilo: Herceg-Novi - 17; Topla - 3; Kotor - 20; Dobrota - 3; Muo - 2; Prčanj - 1; Risan - 2. No u tablici u Prilogu 3 koja se odnosi na vojsku naveden je i broj pripadnika 
drugih vjera jer su među vojnicima njihov broj i udio bili daleko veći. Za razliku od kategorije »S/C+«, u tablicama nema one koja bi se odnosila na doseljenike s utvrđenom hrvatskom etničkom pripadnošću (npr. »H+«), prvenstveno zato što se broj takvih doseljenika mogao utvrditi samo za četiri naselja općine Spič. Stoga ovdje donosimo podatke o tim useljenicima (30) po naseljima: Brca - 4; Šušanj - 9; Sutomore - 13; Zankovići - 4, uz naznaku da je u ovom slučaju najvjerojatnije bila riječ o doseljenicima iz susjednoga barskog okružja, koje je tada pripadalo Crnoj Gori.

Napokon, kako se može vidjeti, postotni suodnosi izračunati su samo u kontekstu podataka o Hrvatima i Srbima/Crnogorcima. Oni se mogu dobiti i na relaciji broja muških i ženskih stanovnika Boke Kotorske te pripadnika jezičnih skupina. No s obzirom na fokus našeg istraživanja unos takvih podataka u priložene, prostorno ograničene tablice nije bio nužan.

Tablica 1. Okrug Budva, 1900.

Table 1. Budva county, 1900

\begin{tabular}{|c|c|c|c|c|c|c|c|c|c|c|c|c|c|c|}
\hline & UK & $\mathbf{M}$ & Ž & JEZ & $\mathrm{SH}$ & NJ & $\mathrm{T}$ & OST & N-J & $\mathbf{H}$ & $\%$ & $\mathrm{~S} / \mathrm{C}$ & $\%$ & $\mathrm{~S} / \mathrm{C}+$ \\
\hline 1. BUDVA & 6741 & 2919 & 3822 & 6174 & 6127 & 3 & 37 & 7 & 567 & 1170 & 17,4 & 5524 & 82 & 250 \\
\hline 1.1. BUDVA & 2620 & 1219 & 1401 & 2386 & 2342 & 3 & 35 & 6 & 234 & 308 & 11,8 & 2268 & 86,6 & 47 \\
\hline 1 Budva & 756 & 345 & 411 & 576 & 535 & 2 & 35 & 4 & 180 & 301 & 39,8 & 414 & 54,8 & - \\
\hline 2 Maini Sr. & 322 & 157 & 165 & 321 & 321 & - & - & - & 1 & - & - & 322 & 100 & 1 \\
\hline 3 Maini Kr. & 304 & 153 & 151 & 295 & 293 & 1 & - & 1 & 9 & 3 & 1 & 299 & 98,4 & 6 \\
\hline 4 Martinovići & 185 & 83 & 102 & 171 & 171 & - & - & - & 14 & - & - & 185 & 100 & 14 \\
\hline 5 Pobori D. & 173 & 73 & 100 & 166 & 165 & - & - & 1 & 7 & 4 & 2,3 & 168 & 97,1 & 3 \\
\hline 6 Pobori G. & 63 & 25 & 38 & 55 & 55 & - & - & - & 8 & - & - & 63 & 100 & 8 \\
\hline 7 Podostrog & 349 & 161 & 188 & 341 & 341 & - & - & - & 8 & - & - & 349 & 100 & 8 \\
\hline 8 Prentovići & 97 & 52 & 45 & 92 & 92 & - & - & - & 5 & - & - & 97 & 100 & 5 \\
\hline 9 Seoca & 36 & 16 & 20 & 36 & 36 & - & - & - & 0 & - & - & 36 & 100 & - \\
\hline 10 Stojanovići & 176 & 88 & 88 & 175 & 175 & - & - & - & 1 & - & - & 176 & 100 & 1 \\
\hline 11 Uglješići & 159 & 66 & 93 & 158 & 158 & - & - & - & 1 & - & - & 159 & 100 & 1 \\
\hline
\end{tabular}

\begin{tabular}{|c|c|c|c|c|c|c|c|c|c|c|c|c|c|c|}
\hline 1.2. PAŠTROVIĆI & 2789 & 1215 & 1574 & 2570 & 2567 & - & 2 & 1 & 219 & 35 & 1,3 & 2751 & 98,6 & 184 \\
\hline 1 Bečići & 155 & 66 & 89 & 149 & 149 & & - & - & 6 & 3 & 1,9 & 152 & 98,1 & 3 \\
\hline 2 Blizikuće & 69 & 18 & 51 & 65 & 65 & 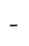 & - & & 4 & - & - & 69 & 100 & 4 \\
\hline 3 Buljarica & 253 & 134 & 119 & 154 & 154 & - & - & 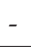 & 99 & - & - & 253 & 100 & 99 \\
\hline 4 Kastel Lastva & 373 & 172 & 201 & 317 & 315 & - & 2 & - & 56 & 21 & 5,6 & 350 & 93,8 & 35 \\
\hline
\end{tabular}




\begin{tabular}{|c|c|c|c|c|c|c|c|c|c|c|c|c|c|c|}
\hline & UK & $\mathbf{M}$ & Ž & JEZ & $\mathrm{SH}$ & NJ & $\mathrm{T}$ & OST & N-J & $\mathbf{H}$ & $\%$ & $\mathrm{~S} / \mathrm{C}$ & $\%$ & $\mathrm{~S} / \mathrm{C}+$ \\
\hline 5 Čelebrdo & 170 & 67 & 103 & 164 & 164 & - & - & - & 6 & 5 & 2,9 & 165 & 97,1 & 1 \\
\hline 6 Dabkovići & 49 & 26 & 23 & 49 & 49 & - & 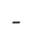 & - & 0 & - & - & 49 & 100 & - \\
\hline 7 Drobnići & 93 & 37 & 56 & 93 & 93 & - & 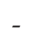 & - & 0 & - & - & 93 & 100 & - \\
\hline 8 Đenaši & 66 & 22 & 44 & 62 & 62 & - & - & - & 4 & - & - & 66 & 100 & 4 \\
\hline 9 Kaluđerac & 144 & 63 & 81 & 136 & 136 & - & - & - & 8 & - & - & 144 & 100 & 8 \\
\hline 10 Katun & 166 & 74 & 92 & 157 & 157 & - & - & - & 9 & 1 & 0,6 & 165 & 99,4 & 8 \\
\hline 11 Krstac & 154 & 65 & 89 & 154 & 154 & - & - & - & 0 & - & - & 154 & 100 & - \\
\hline 12 Kuljače & 93 & 38 & 55 & 90 & 90 & - & - & - & 3 & - & - & 93 & 100 & 3 \\
\hline 13 Novoselje & 152 & 74 & 78 & 144 & 143 & - & - & 1 & 8 & 5 & 3,3 & 146 & 96,1 & 3 \\
\hline 14 Podbabac & 61 & 26 & 35 & 61 & 61 & - & - & - & 0 & - & - & 61 & 100 & - \\
\hline 15 Pržno & 155 & 65 & 90 & 155 & 155 & - & - & - & 0 & - & - & 155 & 100 & - \\
\hline 16 Sv. Stefan & 117 & 46 & 71 & 112 & 112 & - & - & - & 5 & - & - & 117 & 100 & 5 \\
\hline 17 Tudorovići & 226 & 102 & 124 & 226 & 226 & - & - & - & 0 & - & - & 226 & 100 & \\
\hline 18 Vrba & 110 & 39 & 71 & 105 & 105 & - & - & - & 5 & - & - & 110 & 100 & 5 \\
\hline 19 Zukovica & 183 & 81 & 102 & 177 & 177 & - & - & - & 6 & - & - & 183 & 100 & 6 \\
\hline 1.3. SPIČ & 1332 & 485 & 847 & 1218 & 1218 & - & - & - & 114 & 827 & 62,1 & 505 & 37,9 & 19 \\
\hline 1 Brca & 148 & 51 & 97 & 134 & 134 & - & - & - & 14 & 138 & 93,2 & 10 & 6,8 & - \\
\hline 2 Đenđinović & 206 & 68 & 138 & 189 & 189 & - & - & - & 17 & 134 & 65 & 72 & 35 & - \\
\hline 3 Đurmani & 89 & 27 & 62 & 84 & 84 & - & - & - & 5 & 1 & 1,1 & 88 & 98,9 & 4 \\
\hline 4 Miljevci & 85 & 29 & 56 & 82 & 82 & - & - & - & 3 & 81 & 95,3 & 4 & 4,7 & - \\
\hline 5 Mišići & 140 & 65 & 75 & 133 & 133 & - & - & - & 7 & - & - & 140 & 100 & 7 \\
\hline 6 Papani & 123 & 46 & 77 & 112 & 112 & - & - & - & 11 & 3 & 2,4 & 120 & 97,6 & 8 \\
\hline 7 Šušanj & 293 & 91 & 202 & 260 & 260 & - & - & - & 33 & 269 & 91,8 & 24 & 8,2 & - \\
\hline 8 Sutomore & 73 & 40 & 33 & 56 & 56 & - & - & - & 17 & 69 & 94,5 & 4 & 5,5 & - \\
\hline 9 Zagrađe & 62 & 24 & 38 & 62 & 62 & - & - & - & 0 & 22 & 35,5 & 40 & 64,5 & - \\
\hline 10 Zankovići & 113 & 44 & 69 & 106 & 106 & - & - & - & 7 & 110 & 97,4 & 3 & 2,6 & - \\
\hline
\end{tabular}

Izvor: Gemeindelexikon von Dalmatien, Volkszählung vom 31. Dezember 1900., Wien, 1908. 
Tablica 2. Okrug Herceg-Novi, 1900.

Table 2. Herceg-Novi county, 1900

\begin{tabular}{|c|c|c|c|c|c|c|c|c|c|c|c|c|c|c|}
\hline & UK & $\mathbf{M}$ & Ž & JEZ & SH & NJ & $\mathbf{T}$ & OST & N-J & $\mathbf{H}$ & $\%$ & $\mathrm{~S} / \mathrm{C}$ & $\%$ & $\mathrm{~S} / \mathrm{C}+$ \\
\hline 2. H-NOVI & 8751 & 4268 & 4483 & 8195 & 8000 & 42 & 109 & 44 & 556 & 1188 & 13,6 & 7368 & 84,2 & 62 \\
\hline 2.1. H-NOVI & 7623 & 3746 & 3877 & 7067 & 6872 & 42 & 109 & 44 & 556 & 1059 & 13,9 & 6369 & 83,5 & 62 \\
\hline 1 Baošići & 288 & 133 & 155 & 279 & 279 & - & - & - & 9 & 33 & 11,5 & 255 & 88,5 & - \\
\hline 2 Bijela & 668 & 335 & 333 & 650 & 649 & - & - & 1 & 18 & 23 & 3,4 & 644 & 96,4 & - \\
\hline 3 Herceg-Novi & 1078 & 508 & 570 & 888 & 755 & 34 & 82 & 17 & 190 & 641 & 59,5 & 304 & 28,2 & - \\
\hline 4 Đenovići & 249 & 126 & 123 & 243 & 240 & - & 1 & 2 & 6 & 25 & 10 & 221 & 88,8 & - \\
\hline 5 Jošica & 160 & 82 & 78 & 150 & 150 & - & - & - & 10 & 38 & 23,8 & 122 & 76,3 & - \\
\hline 6 Kameno & 456 & 218 & 238 & 442 & 442 & - & - & - & 14 & 2 & 0,4 & 454 & 99,6 & 12 \\
\hline 7 Kruševice & 319 & 161 & 158 & 319 & 319 & - & - & - & 0 & - & - & 319 & 100 & - \\
\hline 8 Kumbor & 225 & 100 & 125 & 212 & 210 & - & 2 & - & 13 & 20 & 8,9 & 203 & 90,2 & - \\
\hline 9 Kuti & 727 & 366 & 361 & 702 & 693 & - & 9 & - & 25 & 11 & 1,5 & 707 & 97,2 & 14 \\
\hline 10 Mojdež & 555 & 277 & 278 & 546 & 546 & - & - & - & 9 & - & - & 555 & 100 & 9 \\
\hline 11 Mokrine & 690 & 346 & 344 & 681 & 680 & - & - & 1 & 9 & 4 & 0,6 & 685 & 99,3 & 5 \\
\hline 12 Podi & 438 & 206 & 232 & 400 & 398 & - & 2 & - & 38 & 29 & 6,6 & 407 & 92,9 & 9 \\
\hline 13 Ratiševina & 192 & 98 & 94 & 191 & 191 & - & - & - & 1 & - & - & 192 & 100 & 1 \\
\hline 14 Sasovići & 219 & 106 & 113 & 215 & 202 & 2 & 6 & 5 & 4 & 10 & 4,6 & 196 & 89,5 & - \\
\hline 15 Savina & 236 & 121 & 115 & 185 & 174 & 3 & 2 & 6 & 51 & 67 & 28,4 & 158 & 66,9 & - \\
\hline 16 Sušćepan & 132 & 68 & 64 & 132 & 132 & - & - & - & 0 & 9 & 6,8 & 123 & 93,2 & - \\
\hline 17 Topla & 668 & 344 & 324 & 512 & 492 & 3 & 5 & 12 & 156 & 147 & 22 & 501 & 75 & 9 \\
\hline 18 Trebesinj & 184 & 78 & 106 & 181 & 181 & - & - & - & 3 & - & - & 184 & 100 & 3 \\
\hline 19 Žlijebi & 139 & 73 & 66 & 139 & 139 & - & - & - & 0 & - & - & 139 & 100 & - \\
\hline 2.2. LUŠTICA & 1128 & 522 & 606 & 1128 & 1128 & - & - & - & - & 129 & 11,4 & 999 & 88,6 & - \\
\hline 1 Babunci & 57 & 23 & 34 & 57 & 57 & - & - & - & - & - & - & 57 & 100 & - \\
\hline 2 Brguli & 174 & 77 & 97 & 174 & 174 & - & - & - & - & - & - & 174 & 100 & - \\
\hline 3 Klinci & 144 & 70 & 74 & 144 & 144 & - & - & - & - & 2 & 1,4 & 142 & 98,6 & - \\
\hline 4 Krašići & 124 & 57 & 67 & 124 & 124 & - & - & - & - & 118 & 95,2 & 6 & 4,8 & - \\
\hline 5 Mrkovi & 145 & 70 & 75 & 145 & 145 & - & - & - & - & 3 & 2,1 & 142 & 97,9 & - \\
\hline 6 Rose & 33 & 16 & 17 & 33 & 33 & - & - & - & - & 6 & 18,2 & 27 & 81,8 & - \\
\hline 7 Radovanići & 284 & 131 & 153 & 284 & 284 & - & - & - & - & - & - & 284 & 100 & - \\
\hline 8 Zabrđe & 167 & 78 & 89 & 167 & 167 & - & - & - & - & - & - & 167 & 100 & - \\
\hline
\end{tabular}

Izvor: Gemeindelexikon von Dalmatien, Volkszählung vom 31. Dezember 1900., Wien, 1908. 
Tablica 3. Okrug Kotor, 1900.

Table 3. Kotor county, 1900

\begin{tabular}{|c|c|c|c|c|c|c|c|c|c|c|c|c|c|c|}
\hline & UK & $\mathbf{M}$ & Ž & JEZ & SH & NJ & $\mathbf{T}$ & OST & N-J & $\mathbf{H}$ & $\%$ & $\mathrm{~S} / \mathrm{C}$ & $\%$ & $\mathrm{~S} / \mathrm{C}+$ \\
\hline 3. KOTOR & 13.771 & 6471 & 7300 & 12.672 & 12.173 & 63 & 409 & 27 & 1099 & 6434 & 46,7 & 6838 & 49,7 & 76 \\
\hline 3.1. KOTOR & 4589 & 2237 & 2352 & 3979 & 3588 & 43 & 325 & 23 & 610 & 2580 & 56,2 & 1618 & 35,3 & 13 \\
\hline 1 Bogdašići & 346 & 176 & 170 & 344 & 344 & - & - & - & 2 & 325 & 93,9 & 21 & 6,1 & - \\
\hline 2 Kotor & 2274 & 1080 & 1194 & 1813 & 1451 & 33 & 310 & 19 & 461 & 1194 & 52,5 & 718 & 31,6 & - \\
\hline 3 Kavač & 221 & 119 & 102 & 184 & 184 & - & - & - & 37 & 78 & 35,3 & 143 & 64,7 & - \\
\hline 4 Lepetane & 273 & 124 & 149 & 262 & 262 & - & - & - & 11 & 207 & 75,8 & 66 & 24,2 & - \\
\hline 5 Mrčevac & 93 & 53 & 40 & 93 & 93 & - & - & - & 0 & 79 & 84,9 & 14 & 15,1 & - \\
\hline 6 Orahovac & 569 & 265 & 304 & 538 & 538 & - & - & - & 31 & 18 & 3,2 & 551 & 96,8 & 13 \\
\hline 7 Škaljari & 713 & 372 & 341 & 645 & 616 & 10 & 15 & 4 & 68 & 580 & 81,3 & 104 & 14,6 & - \\
\hline 8 Špiljari & 100 & 48 & 52 & 100 & 100 & - & - & - & 0 & 99 & 99 & 1 & 1 & - \\
\hline 3.2. DOBROTA & 1043 & 463 & 580 & 774 & 762 & 3 & 6 & 3 & 269 & 764 & 73,3 & 267 & 25,6 & - \\
\hline 3.3. KRTOLE & 1028 & 474 & 554 & 1025 & 1025 & - & - & - & 3 & 108 & 10,5 & 920 & 89,5 & - \\
\hline 1 Bogišići & 205 & 91 & 114 & 203 & 203 & - & - & - & 2 & 81 & 39,5 & 124 & 60,5 & - \\
\hline 2 Đuraševići & 170 & 84 & 86 & 170 & 170 & - & - & - & 0 & 1 & 0,6 & 169 & 99,4 & - \\
\hline 3 Gošići & 243 & 123 & 120 & 243 & 243 & - & - & - & 0 & 10 & 4,1 & 233 & 95,9 & - \\
\hline 4 Milovići & 156 & 68 & 88 & 156 & 156 & - & - & - & 0 & 1 & 0,6 & 155 & 99,4 & - \\
\hline 5 Nikovići & 60 & 29 & 31 & 60 & 60 & - & - & - & 0 & 2 & 3,3 & 58 & 96,7 & - \\
\hline 6 Radovići & 194 & 79 & 115 & 193 & 193 & - & - & - & 1 & 13 & 6,7 & 181 & 93,3 & - \\
\hline 3.4. LASTVA & 754 & 327 & 427 & 753 & 752 & 1 & - & - & 1 & 742 & 98,4 & 11 & 1,5 & - \\
\hline 1 Lastva Donja & 314 & 146 & 168 & 313 & 312 & 1 & - & - & 1 & 302 & 96,2 & 11 & 3,5 & - \\
\hline 2 Lastva G. & 440 & 181 & 259 & 440 & 440 & - & - & - & 0 & 440 & 100 & - & - & - \\
\hline 3.5. MUO & 653 & 322 & 331 & 617 & 572 & 10 & 34 & 1 & 36 & 501 & 76,7 & 107 & 16,4 & - \\
\hline 3.6. PRČANJ & 645 & 256 & 389 & 578 & 549 & 3 & 26 & - & 67 & 516 & 80 & 100 & 15,5 & - \\
\hline 3.7. STOLIV & 347 & 157 & 190 & 321 & 318 & - & 3 & - & 26 & 296 & 85,3 & 48 & 13,8 & - \\
\hline 1 Stoliv Donji & 238 & 109 & 129 & 213 & 210 & - & 3 & - & 25 & 188 & 79 & 47 & 19,7 & - \\
\hline 2 Stoliv Gornji & 109 & 48 & 61 & 108 & 108 & & & & 1 & 108 & 99,1 & 1 & 0,9 & - \\
\hline 3.8. TIVAT & 942 & 432 & 510 & 936 & 918 & 3 & 15 & - & 6 & 906 & 96,2 & 18 & 1,9 & - \\
\hline
\end{tabular}




\begin{tabular}{|c|c|c|c|c|c|c|c|c|c|c|c|c|c|c|}
\hline & UK & $\mathbf{M}$ & Ž & JEZ & SH & NJ & $\mathrm{T}$ & OST & N-J & $\mathbf{H}$ & $\%$ & $\mathrm{~S} / \mathrm{C}$ & $\%$ & $\mathrm{~S} / \mathrm{C}+$ \\
\hline 3.9. GRBALJ & 3770 & 1803 & 1967 & 3689 & 3689 & - & - & - & 81 & 21 & 0,6 & 3749 & 99,4 & 63 \\
\hline 1 Bratešići & 99 & 49 & 50 & 99 & 99 & - & - & - & 0 & 3 & 3 & 96 & 97 & - \\
\hline 2 Dub & 138 & 71 & 67 & 129 & 129 & - & - & - & 9 & - & - & 138 & 100 & 9 \\
\hline 3 Glavati & 200 & 105 & 95 & 197 & 197 & - & - & - & 3 & - & - & 200 & 100 & 3 \\
\hline 4 Glavatičići & 425 & 209 & 216 & 419 & 419 & - & - & - & 6 & 2 & 0,5 & 423 & 99,5 & 4 \\
\hline 5 Gorovići & 170 & 77 & 93 & 169 & 169 & - & - & - & 1 & - & - & 170 & 100 & 1 \\
\hline 6 Kovači & 146 & 66 & 80 & 146 & 146 & - & - & - & 0 & - & - & 146 & 100 & - \\
\hline 7 Krimovica & 175 & 79 & 96 & 175 & 175 & - & - & - & 0 & - & - & 175 & 100 & - \\
\hline 8 Kubasi & 318 & 150 & 168 & 311 & 311 & - & - & - & 7 & 1 & 0,3 & 317 & 99,7 & 6 \\
\hline 9 Lastva & 151 & 70 & 81 & 151 & 151 & - & - & - & 0 & - & - & 151 & 100 & - \\
\hline 10 Lješevići & 104 & 50 & 54 & 95 & 95 & - & - & - & 9 & - & - & 104 & 100 & 9 \\
\hline 11 Nalježići & 209 & 99 & 110 & 206 & 206 & - & - & - & 3 & - & - & 209 & 100 & 3 \\
\hline 12 Pelinovo & 119 & 54 & 65 & 113 & 113 & - & - & - & 6 & 4 & 3,4 & 115 & 96,6 & 2 \\
\hline 13 Pobrđe & 207 & 95 & 112 & 205 & 205 & - & - & - & 2 & - & - & 207 & 100 & 2 \\
\hline 14 Prijeradi & 137 & 59 & 78 & 135 & 135 & - & - & - & 2 & - & - & 137 & 100 & 2 \\
\hline 15 Prijevor & 129 & 62 & 67 & 118 & 118 & - & - & - & 11 & - & - & 129 & 100 & 11 \\
\hline 16 Šišići & 358 & 185 & 173 & 349 & 349 & - & - & - & 9 & 8 & 2,2 & 350 & 97,8 & 1 \\
\hline 17 Sutvara & 90 & 40 & 50 & 84 & 84 & - & - & - & 6 & - & - & 90 & 100 & 6 \\
\hline 18 Višnjevo & 125 & 60 & 65 & 121 & 121 & - & - & - & 4 & 3 & 2,4 & 122 & 97,6 & 1 \\
\hline 19 Vranovići & 250 & 114 & 136 & 247 & 247 & - & - & - & 3 & - & - & 250 & 100 & 3 \\
\hline 20 Zagora & 220 & 109 & 111 & 220 & 220 & - & - & - & 0 & - & - & 220 & 100 & - \\
\hline
\end{tabular}

Izvor: Gemeindelexikon von Dalmatien, Volkszählung vom 31. Dezember 1900., Wien, 1908.

Tablica 4. Okrug Risan, 1900.

Table 4. Risan county, 1900

\begin{tabular}{|c|c|c|c|c|c|c|c|c|c|c|c|c|c|c|}
\hline & UK & $\mathbf{M}$ & Ž & JEZ & $\mathrm{SH}$ & NJ & $\mathbf{T}$ & OST & N-J & $\mathbf{H}$ & $\%$ & $\mathrm{~S} / \mathrm{C}$ & $\%$ & $\mathrm{~S} / \mathrm{C}+$ \\
\hline 4. RISAN & 4852 & 2369 & 2483 & 4619 & 4556 & 8 & 46 & 9 & 233 & 773 & 15,9 & 4016 & 82,8 & 48 \\
\hline 4.1. PERAST & 930 & 430 & 500 & 875 & 874 & - & 1 & - & 55 & 618 & 66,5 & 311 & 33,4 & - \\
\hline 1 Đurići & 194 & 107 & 87 & 189 & 189 & - & - & - & 5 & 153 & 78,9 & 41 & 21,1 & - \\
\hline 2 Kostanjica & 206 & 87 & 119 & 194 & 194 & - & - & - & 12 & 105 & 51 & 101 & 49 & - \\
\hline 3 Perast & 345 & 148 & 197 & 312 & 311 & - & 1 & - & 33 & 220 & 63,8 & 124 & 35,9 & - \\
\hline 4 Strp-Lipci & 185 & 88 & 97 & 180 & 180 & - & - & - & 5 & 140 & 75,7 & 45 & 24,3 & - \\
\hline 4.2. RISAN & 3922 & 1939 & 1983 & 3744 & 3682 & 8 & 45 & 9 & 178 & 155 & 4 & 3705 & 94,5 & 48 \\
\hline 1 Krivošije D. & 657 & 336 & 321 & 633 & 627 & 4 & 1 & 1 & 24 & 10 & 1,5 & 641 & 97,6 & 14 \\
\hline
\end{tabular}




\begin{tabular}{|c|c|c|c|c|c|c|c|c|c|c|c|c|c|c|c|}
\hline & & UK & $\mathbf{M}$ & Ž & JEZ & $\mathrm{SH}$ & NJ & $\mathbf{T}$ & OST & N-J & $\mathbf{H}$ & $\%$ & $\mathrm{~S} / \mathrm{C}$ & $\%$ & $\mathrm{~S} / \mathrm{C}+$ \\
\hline 2 & Krivošije G. & 735 & 389 & 346 & 713 & 713 & - & - & - & 22 & 13 & 1,8 & 722 & 98,2 & 9 \\
\hline 3 & Ledenice D. & 111 & 60 & 51 & 110 & 110 & - & - & - & 1 & - & - & 111 & 100 & 1 \\
\hline 4 & Ledenice G. & 201 & 113 & 88 & 194 & 194 & - & - & - & 7 & 12 & 6 & 189 & 94 & - \\
\hline 5 & Morinj & 570 & 261 & 309 & 535 & 523 & 1 & 11 & - & 35 & 11 & 1,9 & 547 & 96 & 24 \\
\hline 6 & Risan & 1117 & 541 & 576 & 1029 & 985 & 3 & 33 & 8 & 88 & 102 & 9,1 & 971 & 86,9 & - \\
\hline 7 & Ubli & 531 & 239 & 292 & 530 & 530 & - & - & - & 1 & 7 & 1,3 & 524 & 98,7 & - \\
\hline
\end{tabular}

Izvor: Gemeindelexikon von Dalmatien, Volkszählung vom 31. Dezember 1900., Wien, 1908.

Tablica 5. Kotar Kotor, 1900.

Table 5. Kotor district, 1900

\begin{tabular}{|c|c|c|c|c|c|c|c|c|c|c|c|c|c|}
\hline & UK & $\mathbf{M}$ & Ž & JEZ & SH & NJ & $\mathrm{T}$ & OST & N-J & $\mathbf{H}$ & $\%$ & $\mathrm{~S} / \mathrm{C}$ & $\% \quad \mathrm{~S} / \mathrm{C}+$ \\
\hline 1. BUDVA & 6741 & 2919 & 3822 & 6174 & 6127 & 3 & 37 & 7 & 567 & 1170 & 17,4 & 5524 & 81,9250 \\
\hline $2 \mathrm{H}-\mathrm{NOVI}$ & 8751 & 4268 & 4483 & 8195 & 8000 & 42 & 109 & 44 & 556 & 1188 & 13,6 & 7368 & $84,2 \quad 62$ \\
\hline 3 KOTOR & 13.771 & 6471 & 7300 & 12.672 & 12.173 & 63 & 409 & 27 & 1099 & 6434 & 46,7 & 6838 & $49,7 \quad 76$ \\
\hline 4 RISAN & 4852 & 2369 & 2483 & 4619 & 4556 & 8 & 46 & 9 & 233 & 773 & 15,9 & 4016 & $82,8 \quad 48$ \\
\hline
\end{tabular}

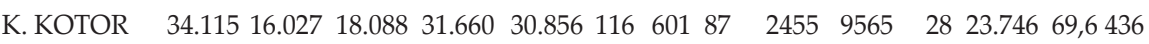

\begin{tabular}{|c|c|c|c|c|c|c|c|c|c|c|c|}
\hline 1.1. BUDVA & 2620 & 1219 & 1401 & 2386 & 2342 & 3 & 35 & 6 & 234 & 30811,8 & $2268 \quad 86,6 \quad 47$ \\
\hline 1.2. PAŠTROVIĆI & 2789 & 1215 & 1574 & 2570 & 2567 & - & 2 & 1 & 219 & $35 \quad 1,3$ & 275198,6184 \\
\hline 1.3. SPIČ & 1332 & 485 & 847 & 1218 & 1218 & - & - & - & 114 & 82762,1 & $505 \quad 37,9 \quad 19$ \\
\hline 2.1. H-NOVI & 7623 & 3746 & 3877 & 7067 & 6872 & 42 & 109 & 44 & 556 & 105913,9 & $636983,5 \quad 62$ \\
\hline 2.2. LUŠTICA & 1128 & 522 & 606 & 1128 & 1128 & - & - & - & 0 & 12911,4 & 99988,6 \\
\hline 3.1. KOTOR & 4589 & 2237 & 2352 & 3979 & 3588 & 43 & 325 & 23 & 610 & 258056,2 & $161835,3 \quad 13$ \\
\hline 3.2. DOBROTA & 1043 & 463 & 580 & 774 & 762 & 3 & 6 & 3 & 269 & 76473,3 & 26725,6 \\
\hline 3.3. KRTOLE & 1028 & 474 & 554 & 1025 & 1025 & - & - & - & 3 & 10810,5 & 92089,5 \\
\hline 3.4. LASTVA & 754 & 327 & 427 & 753 & 752 & 1 & - & - & 1 & 74298,4 & $11 \quad 1,5$ \\
\hline 3.5. MUO & 653 & 322 & 331 & 617 & 572 & 10 & 34 & 1 & 36 & 50176,7 & 10716,4 \\
\hline 3.6. PRČANJ & 645 & 256 & 389 & 578 & 549 & 3 & 26 & - & 67 & $516 \quad 80$ & 10015,5 \\
\hline 3.7. STOLIV & 347 & 157 & 190 & 321 & 318 & - & 3 & - & 26 & 29685,3 & $48 \quad 13,8$ \\
\hline 3.8. TIVAT & 942 & 432 & 510 & 936 & 918 & 3 & 15 & - & 6 & 90696,2 & $18 \quad 1,9$ \\
\hline 3.9. GRBALJ & 3770 & 1803 & 1967 & 3689 & 3689 & - & - & - & 81 & $21 \quad 0,6$ & $374999,4 \quad 63$ \\
\hline 4.1. PERAST & 930 & 430 & 500 & 875 & 874 & - & 1 & - & 55 & $618 \quad 66,5$ & 31133,4 \\
\hline 4.2. RISAN & 3922 & 1939 & 1983 & 3744 & 3682 & 8 & 45 & 9 & 178 & 155 & $370594,5 \quad 48$ \\
\hline
\end{tabular}

Izvor: Gemeindelexikon von Dalmatien, Volkszählung vom 31. Dezember 1900., Wien, 1908. 


\section{RAZMATRANJE POPISNIH REZULTATA}

Boka Kotorska bila je, a donekle je i do danas prepoznatljiva kao prostor koji je u vjerskom i etničkom smislu heterogen. Gledajući u cjelini, na razini kotara Kotor, dakle Boke u širem smislu, u njoj je 1900. obitavalo 34.115 stanovnika, od čega 9565 ili 28\% Hrvata te 23.746 ili 69,6\% Srba/Crnogoraca. Na tlu samih okruga Herceg-Novi, Risan i Kotor živjelo je 1900. godine 27.374 stanovnika, od čega 8395 ili 30,7\% Hrvata te 18.222 ili 66,6\% Srba/Crnogoraca.

Navedene brojčane suodnose Hrvata te Srba/Crnogoraca potvrđuje i popis iz 1921., koji je proveden nakon raspada Austro-Ugarske i uspostave Kraljevine Srba, Hrvata i Slovenaca (od 1929. Kraljevina Jugoslavija). I u ovom slučaju riječ je bila o popisu koji nije evidentirao etničku, već vjersku i jezičnu pripadnost. No zbog brojnosti jezičnih odrednica te stoga što je izjašnjavanje o jeziku obuhvatilo ukupno stanovništvo, tim je popisom omogućeno stjecanje dobrog uvida u etničke suodnose na tlu Boke Kotorske. Popisom iz 1921. bilo je obuhvaćeno "prisutno stanovništvo (građansko i vojničko, trajno i prolazno prisutno)«. Za razliku od onog iz 1900. on ne dopušta izdvajanje vojnika iz ukupnog stanovništva. No budući da je raspadom Austro-Ugarske Boka izgubila nekadašnji vojni značaj, u njoj je 1921. bilo neusporedivo manje stacioniranih vojnika. Sukladno etničkom sastavu novonastale države očekivano je da su oni, u mjeri u kojoj su se mogli nalaziti u Boki, uglavnom bili pravoslavne vjere.

Na razini nekadašnjeg kotara Kotor, koji je u vrijeme popisa iz 1921. imao iste »vanjske« granice (»unutrašnje « su djelomično promijenjene formiranjem općine Petrovac), živjelo je 35.305 stanovnika, od čega 9872 ili 28\% Hrvata te 24.319 ili 69,9\% Srba/Crnogoraca. ${ }^{2}$ Godine 1921. unutar samih okruga Herceg-Novi, Risan i Kotor obitavalo je 29.280 stanovnika, od čega 9008 ili 30,76\% Hrvata te 19.181 ili 65,5\% Srba/Crnogoraca (Definitivni rezultati..., 1932). Kako se iz priloženog vidi, suodnosi Hrvata i Srba/Crnogoraca u Boki Kotorskoj bili su 1921. gotovo isti kao i dvadesetak godina prije. ${ }^{3}$

2 Broj Hrvata dobiven je tako da su od ukupnog broja katolika, grkokatolika i protestanata odbijeni govornici slovenskog, »čekoslovačkog«, poljskog, mađarskog, njemačkog, talijanskog, francuskog i engleskog. Do broja Srba/Crnogoraca došlo se tako što su od broja pravoslavaca odbijeni govornici ruskog i rumunjskog.

3 U inače vrijednom radu »Promjene etničkog sastava Boke kotorske (1910. - 2003.g.) s posebnim osvrtom na veliko smanjenje broja Hrvata (Crkvenčić i Schaller, 2007) iznosi se konstatacija da se stanje etničkih suodnosa kakvo je utvrđeno popisom iz 1910. u bitnome izmijenilo do popisa iz 1921. Tvrdi se da se promijenio »odnos udjela katoličkog i pravoslavnog u ukupnom stanovništvu Boke, i to na štetu katolika: udio katolika pao je na nešto manje od $40 \%$, dok je udio pravoslavnih premašio $60 \%$ ukupnog stanovništva. « Tako »da je 1921. g. u području razmatranih 12 općina kotara Kotor živjelo oko 9.000 Hrvata i 
Iz ovdje priloženih tablica, odnosno iz popisnih rezultata može se vidjeti kako se do najnižih razina, do nivoa pojedinačnih naselja, očitovala heterogenost Boke Kotorske 1900. godine. Pritom je uočljivo da su unutar Boke Kotorske shvaćene $u$ širem smislu postojale znatne, praktički posve homogene srpske/crnogorske cjeline. Na samom sjeverozapadu, uglavnom u sklopu općine Risan, nalazio se relativno prostran planinski masiv Orjena od nekih 200 km², koji je bio rijetko naseljen, ali gotovo isključivo Srbima/ Crnogorcima. Sastojao se od naselja Krivošije Donje i Gornje, Ledenice Donje i Gornje te sela Ubli. U tim je mjestima živjelo 2235 stanovnika, od čega 42 ili 1,9\% Hrvata, u osnovi doseljenih, te 2187 ili 97,9\% Srba/Crnogoraca.

Drugu gotovo posve homogenu cjelinu oblikovale su općine Grbalj (bez Lješevića), Budva, Paštrovići te tri homogena srpska/crnogorska naselja zapadnog dijela općine Spič (Đurmani, Mišići i Papani). Na tom je tlu živjelo 9427 stanovnika, od čega 368 ili 3,9\% Hrvata te 9012 ili 95,6\% Srba/Crnogoraca. Hrvati su kao autohtoni živalj obitavali samo u gradu Budvi (301) te kao neznatna manjina u Kastel Lastvi, naknadno preimenovanoj u Petrovac na Moru (21). Tu cjelinu, od nekih $210 \mathrm{~km}^{2}$, zapravo se uopće ne bi moglo promatrati kao dio etnički heterogenog područja da se istočno od nje, u ostatku Spiča i barskog dijela crnogorskog primorja, ne nalazi još jedan, u daljnjem izlaganju također razmatran prostor hrvatsko-srpskog/crnogorskog isprepletanja.

Uočljivo je da je okosnica vjerske i etničke heterogenosti bila u Boki Kotorskoj u užem smislu. Na tom prostoru od nekih $230 \mathrm{~km}^{2}$, koji ne uključuje Krivošije te općinu Grbalj izuzev naselja Lješevići, obitavalo je 21.473 stanovnika, od čega 8332 ili 38,8\% Hrvata te 12.390 ili 57,7\% Srba/Crnogoraca. Pritom je uočljiva razlika u etničkom karakteru zapadnog $\mathrm{i}$ istočnog dijela Boke. Zapadnom dijelu pripadala bi naselja općine Herceg-Novi, tri naselja općine

oko 15.000 Crnogorca i Srba. Dakle, u odnosu na 1910. g. povećan je broj Hrvata, ali još znatno više i broj Crnogoraca, odnosno Srba. Iz tog razloga Hrvati od tada više nisu većinski narod Boke - to sada postaju Crnogorci i Srbi« (Crkvenčić i Schaller, 2007: 72). Navedena je tvrdnja proizišla iz toga što su autori za 1910. godinu analizirali etnički sastav stanovništva »sastavljenog « od populacije: 1. okruga Kotor bez Grblja; 2. SAMO dvaju naselja općine Risan (Morinj i Risan) i svih naselja općine Perast unutar okruga Risan; 3. SAMO šest naselja općine Herceg-Novi (Baošić, Bijela, Đenovići, Jošica, Kumbor i HercegNovi) i svih naselja općine Luštica unutar okruga Herceg-Novi. Za tu cjelinu, iz koje su isključena praktički sva većinski srpska/crnogorska naselja oko Herceg-Novog (od kojih su, između ostalog, i ona udaljenija od obale bila usko povezana s morem i pomorstvom / Luković, 1951: 67-68/) ispravno je zaključeno da je imala hrvatsku većinu. S druge strane, tu istu cjelinu, vjerojatno pogreškom, usporedilo se sa stanjem etničkih odnosa 1921. godine, ali unutar prostora koji zauzimaju: 1. okrug Kotor bez Grblja; 2. SVA naselja okruga Risan; 3. SVA naselja okruga Herceg-Novi. Iz takve, metodološki neodržive usporedbe proizišli su pogrešni zaključci o smanjenju udjela Hrvata, odnosno povećanju udjela Srba/ Crnogoraca u Boki Kotorskoj u kontekstu popisa iz 1910. i 1921. 
Perast (Đurići, Kostanjica i Strp-Lipci) i dva općine Risan (Morinj i Risan). U tom dijelu obitavalo je 9895, stanovnika od čega 1570 ili 15,9\% Hrvata te 8074 ili 81,6\% Srba/Crnogoraca. U istočnoj Boki, koja bi uključivala općinu Luštica, zatim izuzev grbaljske (uz izuzetak naselja Lješevići) sve ostale općine okruga Kotor te jedno mjesto općine Perast (grad Perast) obitavalo je 11.578 stanovnika, od čega 6762 ili 58,4\% Hrvata te 4316 ili 37,3\% Srba/Crnogoraca.

Izložena razlika između »dvije« Boke uvelike se poklapa s činjenicom da je njen zapadni dio najvećim dijelom bio pod Osmanlijama, a istočni pod Mlečanima. Stoga je zanimljivo vidjeti kakva je 1900. godine bila etnička struktura Boke Kotorske po nekadašnjoj liniji osmansko-mletačkog razgraničenja (Milošević, 2008: 11-18). Osmanlijama je nekoć pripadala kompletna zapadna Boka izuzev triju spomenutih naselja općine Perast (Đurići, Kostanjica i Strp-Lipci). Na tom je teritoriju početkom 20. stoljeća obitavalo 9310 stanovnika, od čega 1172 ili 12,6\% Hrvata te 7887 ili 84,7\% Srba/Crnogoraca. Osmanskom dijelu Boke pripadalo je i pravoslavno mjesto Orahovac, pri čemu je njegov donji, priobalni dio bio smješten između Perasta i Dobrote, a gornji, brdski dio sjeveroistočno od Perasta. Zajedno s tim naseljem, na tlu nekadašnje osmanske Boke živjelo je 9879 stanovnika, od čega 1190 ili 12,1\% Hrvata te 8438 ili 85,4\% Srba/Crnogoraca.

Unutar nekadašnjega mletačkog dijela Boke, koji bi odgovarao njenoj istočnoj polovici bez Orahovca, ali uz mjesto Lješevići (Grbalj) i navedena tri naselja općine Perast, živjelo je 11.594 stanovnika, od čega 7142 ili 61,6\% Hrvata te 3952 ili 34,1\% Srba/Crnogoraca. Dakle, od svih bokeljskih Hrvata njih $85,7 \%$ živjelo je u bivšemu mletačkom, a od svih Srba/Crnogoraca njih $68,1 \%$ u bivšemu osmanskom dijelu Boke. Valja naglasiti da je ovdje riječ o uvidu iz 1900. godine, do koje se odvio niz značajnih migracija i prema Boki Kotorskoj i unutar nje same.

Nakon svih povijesnih promjena, raseljavanja, doseljavanja i asimilacija izrazitu srpsku/crnogorsku većinu na prostoru nekadašnje mletačke Boke imale su općine Luštica i Krtole te naselje Lješevići, koje je još tijekom popisa iz 1857. bilo dijelom Krtola (Čoralić, 2004: 190-191). Stoga se i mletački dio može podijeliti na njegov pretežito hrvatski segment, kojem valja pridodati luštičko selo Krašići, te na njegov srpski/crnogorski dio, koji bi sačinjavala sva ostala naselja luštičke općine zajedno s Krtolama i Lješevićem. U prvome, uglavnom katoličkom dijelu živjelo je 9458 stanovnika, od čega 7023 ili 74,3\% Hrvata te 1935 ili 20,5\% Srba/Crnogoraca. S druge strane, na tlu Luštice (bez Krašića), Krtola i Lješevića, gdje je pravoslavna populacija bila snažno prisutna i prije osmanskih osvajanja (Gogić, 2018: 59-68, 509), 
obitavalo je 2136 stanovnika, od čega 119 ili 5,6\% Hrvata te 2017 ili 94,4\% Srba/Crnogoraca.

Nakon što se podrobnije razmotre bokeljski etnički rasporedi i suodnosi, gotovo bi se moglo ustvrditi da su većinski hrvatski krajevi predstavljali otočje okruženo srpskim/crnogorskim etničkim masivom. Preduvjeti za takvu konfiguraciju počeli su se oblikovati još u 13. stoljeću tijekom procesa masovne pravoslavizacije nekadašnjega zahumsko-dukljanskog življa provedenog u okvirima Nemanjićke Srbije. Naknadno su dodatno preoblikovani u korist pravoslavlja, posebice tijekom mletačke uprave. Objektivno gledano, u uvjetima kakvi su bili za njezina trajanja, nužno je bilo snaženje pravoslavne i slabljenje katoličke komponente. Mletačke vlasti, koliko god bile blagonaklone prema katoličanstvu, nisu vodile politiku koja bi bila definirana nekakvim katoličkim interesima. Mletačka Republika uspijevala je obraniti dio katoličkih krajeva na današnjoj crnogorskoj obali, no gotovo svugdje oko njih bio je pravoslavni živalj. Kada je poticala taj živalj na pobune protiv Osmanlija, morala je barem predvodnicima tih pobuna u slučajevima njihova neuspjeha osigurati egzistenciju na vlastitim posjedima. Kad joj je trebala radna snaga za iskorištavanje opustjelih prostora, najekonomičnije je bilo dovesti je iz susjednoga pravoslavnog narodnosnog spremnika (Katušić, 2013: 51-52), no tad se nije moglo dirati u vjeru pravoslavnih podanika.

Također valja istaknuti da je tijekom stalnih, pojedinačnih migracija iz Crne Gore prema mletačkim posjedima bilo prelazaka na katolicizam (Milošević, 2008: 238). S obzirom na njihov stoljetni tijek vjerojatno je da broj Hrvata koji potječu od takvih prevjerenika nije zanemariv. Ipak, glavna značajka procesa koji su uslijedili nakon pada srednjovjekovne srpske države jest da je karakter heterogenosti Boke Kotorske kao i ostatka crnogorskog primorja upravo za mletačke, osmanske te napokon i austrijske dominacije, za koje otpočinju sve masovnije ekonomske migracije iz zaleđa prema priobalju, dodatno preoblikovan »u korist « pravoslavlja te da je do 1900. imao značajke kakve su registrirane tadašnjim popisom.

Sama hrvatska narodnosna okosnica bila je na poluotoku/planini Vrmcu i u podlovćenskom dijelu primorja sa Škaljarima, Kotorom, Špiljarima i Dobrotom. Oko tog bazičnog dijela nalazio se svojevrsni hrvatski arhipelag sastavljen od naselja Perast, Đurići i Kostanjica, Strp-Lipci te Krašići. ${ }^{4}$ Her-

4 U popisu iz 1900. naselja Strp i Lipci prikazana su kao jedinstvena cjelina. No sam Strp bio je većinski hrvatski, dok je u Lipcima bilo podjednako Hrvata i Srba/Crnogoraca. Prema popisu iz 1857., u prvom je mjestu živjelo 77 katolika i 15 pravoslavaca, a u drugom 40 katolika i 44 pravoslavca (Kozličić i Bralić, 2012: 235). 
ceg-Novi je također imao hrvatsku većinu, no nalazio se duboko u srpskoj/ crnogorskoj zoni. Prevladavajuće hrvatski krajevi Boke zauzimali su oko 90 $\mathrm{km}^{2}$ ili prostor veličine otoka Visa. Oni su unatoč određenoj izoliranosti od ostatka hrvatske etničke formacije te najčešće nepovoljnim političko-povijesnim uvjetima gotovo sedamsto godina uspijevali zadržati svoj pretežito katolički, naknadno hrvatski etnički karakter - sve do najnovijeg doba, kada ga u najvećoj mjeri gube prvenstveno zbog masovnih, suvremenih migracija srpske i crnogorske populacije prema Boki Kotorskoj.

U odnosu na taj, daljnji razvoj demografskih i etničkih suodnosa na tlu Boke Kotorske ( $u$ užem smislu), popularne usporedbe između različitih popisnih razdoblja te s njima povezani zaključci vrlo često polaze od okvira koji zauzima prostor suvremenih općina Herceg-Novi, Kotor i Tivat. Pritom treba uzeti u obzir da je njihova teritorijalnost utvrđena krajem pedesetih godina prošlog stoljeća te da ukupno iznosi 616 km² (Bertić, 1987: 230). Po naznačenome upravno-teritorijalnom principu utvrđivanja prostora Boke, nju su 1900. »konstituirali« okruzi Herceg-Novi, Risan i Kotor. Njihova je ukupna veličina bila manja od $616 \mathrm{~km}^{2}$, odnosno iznosila je $518,72 \mathrm{~km}^{2}$. Razlike su nastale poslije, »pripajanjem «Kruševica i Sutorine $\left(85,9 \mathrm{~km}^{2}\right)$ Herceg-Novom te time što je općini Kotor pridodano pet mjesta koja su 1900. bila dijelom Kneževine Crne Gore. Riječ je o Velikim i Malim Zalazima sjeverno od Dobrote te naseljima Mirac, Čavori i Kolužunj lociranim na južnim obroncima Lovćena. Nasuprot tome, nekadašnje kotorsko, odnosno grbaljsko naselje Prijevor prilikom redefinicije upravnih granica u konačnici je pripalo općini Budva te je time »izišlo iz ovako shvaćenog okvira Boke Kotorske.

Izložene promjene nisu samo išle $\mathrm{u}$ prilog teritorijalno-administrativnom uvećanju Boke, već i promjeni etničkih udjela unutar nje s obzirom na to da su prostori koji su joj naknadno pripali (bili) nastanjeni srpskom/crnogorskom populacijom. Stoga dok su 1900. na spomenutih 518,72 km² Hrvati predstavljali 30,7\% stanovništva, iste bi ih godine unutar okvira od $616 \mathrm{~km}^{2}$ bilo manje, odnosno nekih $28 \%$. Dakle, to je postotak koji bi, konkretno na razini hrvatskog življa, bio mjerodavan ako se u odnosu na stanje iz 1900. prave usporedbe definirane prostorom koji zauzimaju suvremene općine Herceg-Novi, Kotor i Tivat. Pritom se može ustvrditi da se taj udio naglo počinje smanjivati tek od šezdesetih godina. Naime, po popisu iz 1961., Hrvata je u ukupnom stanovništvu navedenih općina bilo 8450 ili 22,4\% (Popis stanovništva..., 1994). Zasigurno ih je bilo više s obzirom na to da je u kontinuitetu, otkada popisi uključuju očitovanje o nacionalnoj pripadnosti, pri- 
mjetno da se znatan dio crnogorskih Hrvata izbjegava izjasniti Hrvatima. Primjerice, po prvom takvu popisu, onom iz 1948., na tlu Boke Kotorske evidentirano je samo 5958 Hrvata (Stalno stanovništvo..., 1954). Što je uzrok toj pojavi, koja posve gubi na važnosti dolaskom tih istih ljudi u Hrvatsku ili u dominantno hrvatsko okružje, trebalo bi biti predmetom posebne analize.

Drugu, demografski i teritorijalno manju hrvatsku enklavu predstavljao bi istočni dio Spiča s naseljima Brca, Đenđinović, Miljevci, Šušanj, Sutomore, Zagrađe i Zankovići. ${ }^{5}$ U tim je naseljima 1900. živjelo 980 stanovnika, od čega 823 ili 84\% Hrvata te 157 ili 16\% Srba/Crnogoraca. Ovu cjelinu, koja je 1878. s ostatkom Spiča pripala austrijskoj Kraljevini Dalmaciji, ne može se gledati izdvojeno od ostatka barskog primorja, koje se iste godine našlo u okviru neovisne Crne Gore. U tom, tada crnogorskom dijelu obitavalo je nešto više Hrvata nego u Spiču, i to u naseljima: Zupci, Šušanj, Velembusi, Burtaiši, Stari Bar, Bar, Turčini, Tomba i Čeluga. Od svih tih mjesta jedino su Zupci predstavljali etnički homogeno naselje koje se direktno naslanjalo na Spič. Pritom je istočni Spič sa Zupcima zauzimao četrdesetak km², tj. teritorij veličine otoka Lastova. Ostatak barskih naselja pripadao je mješovitoj zoni u kojoj je pored Crnogoraca obitavao i bošnjački živalj.

Cijeli taj kraj bio je izrazitom iseljeničkom sredinom. Tako je prilikom popisa iz 1921., koji napokon pruža informacije za kompletnu barsku zonu, u Spiču registrirano samo 657 Hrvata. Istovremeno, u nekadašnjem crnogorskom dijelu, u općinama Bar i Zupci-Zaljevo, ukupno je živjelo 5443 stanovnika, od čega 2548 Crnogoraca, između 757 i 1032 Hrvata te između 1484 i 1759 Bošnjaka. Posljednje slavensko primorsko područje prema dominantno albanskim etničkim prostorima Ulcinja i okolice predstavljalo je bošnjačko pleme Mrkojevića, u čijoj je istoimenoj općini tada živjelo 2647 stanovnika, od čega između 2054 i 2218 Bošnjaka (Definitioni rezultati..., 1932). ${ }^{6}$

Tih približno 1400 - 1700 barskih Hrvata predstavljalo je posljednji slavenski identitetni trag nekad napredne barske komune i njene metropolije koja je

5 Zagrađe se samo uvjetno može promatrati kao dio navedene hrvatske enklave s obzirom na to da je 1900. imalo srpsku/crnogorsku većinu (64,5\%), koja je deset godina prije bila manje izrazita $(55,5 \%)$ (Special-Orts-Repertorium..., 1894).

6 Broj Albanaca u navedenim barskim općinama bio je sljedeći: Bar - 92; Zaljevo-Zupci 183; Mrkojevići - 164 (Definitioni rezultati..., 1932). Kako popis ne daje podatke o tome koliko je među njima bilo katolika, a koliko muslimana, nemoguće je doći i do približnog broja Hrvata, odnosno Bošnjaka. Stoga je u proračunima prezentiran najmanji i najveći (svi Albanci uračunati su među katolike/nijedan Albanac nije uvršten u katolike) mogući broj Hrvata. Jednako tako dan je najmanji i najveći (svi Albanci uračunati su među muslimane/nijedan Albanac nije uvršten u muslimane) mogući broj Bošnjaka. Iz oba iznosa koji se odnose na Bošnjake isključen je broj Turaka, odnosno govornika turskog jezika. 
bila okosnicom dukljanske kraljevine i uporištem dinastije Vojislavljevića.? Slično kao i u bokeljskom slučaju, taj etnički otok, koji se stoljećima održavao u krajnje nesklonim okolnostima, napokon je u suvremenim prilikama iščeznuo kao koliko-toliko homogena cjelina, ponajprije pred migracijama srpskog i crnogorskog življa u priobalje. No dok god je opstojao, moglo se govoriti o hrvatsko-srpskoj/crnogorskoj isprepletenosti na najvećem dijelu današnjega crnogorskog primorja.

\section{ZAKLJUČAK}

Popis stanovništva Kraljevine Dalmacije iz 1900. godine prvi je omogućio stjecanje relativno kvalitetne slike o etničkoj strukturi svih naselja Boke Kotorske, a time i nje same u cjelini. Tada »zatečena « slika stvarala se stoljećima i njeno preoblikovanje nastavilo se do danas. Povijesno gledano, današnje crnogorsko primorje bilo je prostorom na kojem je slavenska populacija zarana, uglavnom tijekom 13. stoljeća, podvojena između svoga starijega, katoličkog te »novijega«, pravoslavnog segmenta. Tada ustanovljena heterogenost nije se očuvala $u$ nepromijenjenom obliku do popisa iz 1900. Doduše, okosnica se katoličanstva »od početka« zadržala na tlu kotorske, budvanske i barske komune, no ono je krajem srednjeg vijeka bilo prisutno i kod dijela slavenske populacije izvan njihovih okvira.

Bitnu prekretnicu predstavljat će razdoblje osmanskih osvajanja i uprave nad znatnim dijelom crnogorskog primorja. U tim okolnostima katolicizam doživljava svoju daljnju eroziju ne samo u korist pravoslavlja već i islama, kako zbog prevjeravanja katolika tako i zbog snažnih iseljavanja. Depopulizirani prostori naknadno su postajali pogodnima za useljavanja novih slojeva prvenstveno pravoslavnog življa. Osim toga, za vrijeme osmanske dominacije počinje i proces inkorporacije pravoslavnih vjernika u nekad homogene katoličke sredine, od Kotora i Budve pa nadalje. Time takva naselja s vremenom postaju etnički heterogenima.

Unutar kotara Kotor gotovo homogeni etnički karakter imao je planinski, rijeko naseljeni masiv Orjena s 97,9\% Srba/Crnogoraca. Slično je bilo i u priobalju

7 Sjeverno od Bara, u općinama Šestani i Livari lociranim uz Skadarsko jezero, po popisu iz 1921. živjelo je 2366 stanovnika, od čega 135 pravoslavaca, 963 katolika i 1268 muslimana. Sudeći po materinjem jeziku, pravoslavce bi valjalo smatrati Crnogorcima, a katolike i muslimane Albancima (Definitioni rezultati..., 1932). No dio katolika iz danas (gotovo) raseljenih Šestana i Livara nacionalno se identificira kao Hrvati. Jednako tako Hrvatima se osjećaju i zadarski Arbanasi, koji glavninom potječu iz toga kraja (Marvučić, 2019). Riječ je o činjenicama na koje valja upozoriti, koje usložnjavaju pitanje etničkih suodnosa u Baru i okolici te koje traže posebnu i opsežnu analizu. 
između Kotora i istočnog Spiča, gdje su Srbi/Crnogorci predstavljali 95,6\% stanovništva. Unutar tog dijela primorskog pojasa autohtonog je hrvatskog življa bilo samo u Budvi i Kastel Lastvi. Heterogena je bila Boka Kotorska u užem smislu, u kojoj je bilo 38,8\% Hrvata te 57,7\%. Srba/Crnogoraca, s tim da je u njezinu zapadnom dijelu bilo $81,6 \%$ Srba/Crnogoraca, a u istočnom 58,4\% Hrvata. Navedena distinkcija uvelike se poklapala s političko-povijesnom s obzirom na to da je najveći dio zapadne Boke bio pod Osmanlijama, dok se njen istočni dio glavninom nalazio pod mletačkom vlašću. Tako su 1900. godine Srbi/Crnogorci u nekadašnjemu osmanskom dijelu Boke predstavljali 85,4\%, a Hrvati u nekadašnjemu mletačkom dijelu 61,6\% stanovništva. Pritom se i taj mletački dio sastojao od dvije više ili manje homogene etničke zone. Unutar većinski hrvatske bilo je 74,3\% Hrvata (Vrmac, dio podlovćenskog primorja, Perast, Strp-Lipci, Kostanjica, Đurići i Krašići), a unutar većinski srpske/crnogorske 94,4\% Srba/Crnogoraca (Luštica bez Krašića, Krtole i Lješevići). Posebno zanimljivu cjelinu predstavljao je istočni Spič, u kojem je bilo $84 \%$ Hrvata. Njega valja promatrati u kontekstu barskih vjersko-etničkih prilika određenih i nazočnošću bošnjačke etničke skupine. Upravo je postojanje autohtone hrvatske zajednice $u$ istočnom Spiču i susjednoj barskoj okolici dopuštalo da se priobalje između Herceg-Novog i Bara u cjelini promatra kao prostor hrvatsko-srpskog/crnogorskog isprepletanja.

Područje Boke Kotorske jedna je u nizu ovdašnjih sredina unutar kojih je povijesno oblikovana heterogena etnička slika. Takvi su krajevi istraživački posebno zanimljivi jer je do pojave složene etničke slike moglo doći samo kroz složene političke i društvene procese. Ovdje smo se bavili njenim utvrđivanjem sukladno rezultatima koji su dostupni u popisu iz 1900. godine. Fokus istraživanja bio je na nečemu što se odnosi na razlikovnost i što pruža temeljni uvid u njene značajke. Zasigurno da se takvim pojavama treba baviti kao i svim onim što su uzrokovale. Ponajprije su bile poticajne za nastanak jednoga posebnog društvenog ozračja u kojem se moralo voditi brigu o razlikama i znati kako živjeti s njima. Cjelokupno crnogorsko primorje ima bogato iskustvo u tom smislu.

U tom se iskustvu akumuliralo i mnoštvo problematičnih slojeva, bilo onih koji su samonikli, onih koji su predstavljali refleksije sa šire društvene scene ili onih koji su inkorporirani doseljavanjem pojedinaca s drugačijim kulturno-političkim senzibilitetom. No činjenica je da je unatoč svim razlikovnostima taj isti bokeljski živalj, neovisno o vjeri i promjenjivosti povijesnih uvjeta, očuvao sposobnost koegzistencije i tijekom najgorih iskušenja kroz koja su prošli ovdašnji prostori. Premda je »splet okolnosti« pritom imao svoju ulogu, činjenica je da takvu razvoju nije štetila prepoznatljiva flek- 
sibilnost crnogorskoga primorskog življa neovisno o vjeri, očitovana kroz stoljetnu međusobnu upućenost i mnogostruke, između ostaloga i obiteljske društvene veze. Tome pozitivnom nasljeđu te kulturi koja ga je proizvela također treba pridati odgovarajuću važnost. Jer, naposljetku, možda se upravo na toj razini najbolje očitovao smisao katolicizma i pravoslavlja.

\section{LITERATURA}

Andrijašević, Ž. (2004). Nacija s greškom. Cetinje: Centralna narodna biblioteka »Đurđe Crnojević«.

Banac, I. (1988). Nacionalno pitanje u Jugoslaviji. Zagreb: Globus.

Bertić, I. (ur.) (1987). Veliki geografski atlas Jugoslavije. Zagreb: Sveučilišna naklada Liber.

Bojović, J. P. (ur.) (1991). Stanovništvo slovenskog porijekla u Albaniji: zbornik radova sa međunarodnog naučnog skupa održanog u Cetinju 21, 22. i 23. juna 1990. Titograd: Historijski institut Crne Gore.

Bralić, A. i Ramljak, S. (2010). Demografske prilike u drniškom kraju prema austrijskim popisima pučanstva (1857. - 1910.), Radovi Zavoda za povijesne znanosti HAZU u Zadru, 52: 285-321.

Crkvenčić, I. i Schaller, A. (2005). Boka Kotorska: društveno-političke promjene i razvoj etničkog sastava do 1918. godine, Hrvatski geografski glasnik, 67 (2): 107-122, doi: https://doi.org/10.21861/hgg.2005.67.02.06

Crkvenčić, I. i Schaller, A. (2006). Boka kotorska: Etnički sastav u razdoblju austrijske uprave (1814. - 1918. g.), Hrvatski geografski glasnik, 68 (1): 51-72, doi: https://doi. org/10.21861/hgg.2006.68.01.03

Crkvenčić, I. i Schaller, A. (2007). Promjene etničkog sastava Boke kotorske (1910. 2003.g.) s posebnim osvrtom na veliko smanjenje broja Hrvata, Hrvatski geografski glasnik, 69 (1): 69-100, doi: https://doi.org/10.21861/hgg.2007.69.01.05

Čoralić, L. (2004). Iz prošlosti Boke - tragom iseljenika s poluotoka Luštice u Mlecima (XVI. - XVIII. stoljeće), Zbornik Odsjeka povijesnih znanosti Zavoda za povijesne $i$ društvene znanosti HAZU, 22: 189-211.

Čorović, V. (1995). Istorija Srba. Beograd: Beogradski izdavačko-grafički zavod.

Čulinović, F. (1981). Državnopravni razvitak Jugoslavije. Zagreb: Pravni fakultet u Zagrebu.

Đurović, M. (ur.) (1970). Istorija Crne Gore (knjiga 2., tom 1.). Titograd: Redakcija za istoriju Crne Gore.

Folić, Z. (2013). Istorija Muslimana Crne Gore: 1455-1918., knjiga I. Podgorica: Matica Muslimanska Crne Gore.

Gogić, M. M. (2018). Političko i društveno uređenje Kotora u drugoj polovini XII i XIII vijeku (doktorski rad). Beograd: Univerzitet u Beogradu, Filozofski fakultet.

Ičević, D. (2015). Crnogorska nacija. Beograd: Forum za etničke odnose.

Katušić, M. (2013). Društvena i demografska struktura Kotora u 18. stoljeću (doktorski rad). Zagreb: Sveučilište u Zagrebu, Hrvatski studiji.

Kozličić, M. i Bralić, A. (2012). Stanovništvo Kraljevine Dalmacije prema službenim izračunima i popisima 1828. - 1857. godine. Zadar: Sveučilište u Zadru.

Luković, N. (1951). Boka Kotorska. Cetinje: Narodna knjiga. 
Lutovac, M. V. (1978). Etničke promene u oblasti stare Raške, u: Glas CCCVII Srpske akademije nauka i umetnosti, knjiga 20. Beograd: SANU, Odeljenje društvenih nauka, 205-230.

Makale, M. (1912). Zadnji popis pučanstva u Dalmaciji. Beč: Naklada »Adria«.

Marković, I. (1902). Dukljansko-barska metropolija. Zagreb: Tisak Antuna Scholza.

Marvučić, V. (2019). Novi barski ljetopis, Hrvatsko slovo, 25 (1244): 3-4.

Milošević, M. (2008). Boka Kotorska, Bar i Ulcinj od XV do XVIII vijeka. Podgorica: CID.

Mulić, J. (2015). Sutorina u Boki kotorskoj neotuđivi teritorij Bosne i Hercegovine, Acta geographica Bosniae et Herzegovinae, Posebno izdanje, Sutorina, 37-50.

Obad, S. (2010). Granice Dalmacije prema susjedima tijekom 19. stoljeća. Zadar: Državni arhiv u Zadru.

Peričić, E. (1991). Sclavorum regnum Grgura Barskog. Zagreb: Kršćanska sadašnjost.

Spahić, M., Bušatlija, I., Jekauc, A., Temimović, E., Jahić, H. i Mezetović, A. (2015). Sutorina - uzurpirani geografski teritorij Bosne i Hercegovine, Acta geographica Bosniae et Herzegovinae, Posebno izdanje, Sutorina, 5-22.

Tuno, N., Mulahusić, A., Kozličić, M. i Orešković, Z. (2011). Rekonstrukcija granice sutorinskog izlaza Bosne i Hercegovine na Jadransko more s pomoću starih geografskih karata, Kartografija i geoinformacije, 10 (16): 26-55.

Zefi, S. (2003). Islamizacija Albanaca i fenomen larmarstva tijekom stoljeća (XV. - XX.). Zagreb: Albanska katolička misija.

Živković, D. (1989). Istorija crnogorskog naroda, knjiga I. Cetinje: Izdanje autorovih prijatelja.

Živković, D. (1992). Istorija crnogorskog naroda, knjiga II. Cetinje: DP »Montex«.

\section{IZVORI}

Definitioni rezultati popisa stanovništva od 31. januara 1921. god., Kraljevina Jugoslavija, Opšta državna statistika, Sarajevo, 1932.

Die Ergebnisse der Volkszählung in Bosnien und der Hercegovina vom 10. Oktober 1910., Landesregierung für Bosnien und die Hercegovina, Statistischen Departement der Landesregierung, Sarajevo, 1912.

Gemeindelexikon der im Reichsrate Vertretenen Königreiche und Länder - Bearbeitet auf Grund der Ergebnisse der Volkszählung vom 31. Dezember 1900. - XIV. DALMATIEN., Harausgegeben von der K. K. Statistischen Zentralkommission, Wien, 1908.

Glavni rezultati popisa žiteljstva u Bosni i Hercegovini od 22. aprila 1895., Zemaljska vlada za Bosnu i Hercegovinu, Statistički odjel Zemaljske vlade za Bosnu i Hercegovinu, Sarajevo, 1896.

Popis stanovništva, domaćinstava i stanova u 1961. godini. Nacionalni sastav stanovništva FNR Jugoslavije (podaci po naseljima i opštinama), knjiga III., Savezni zavod za statistiku, Beograd, 1994, http://publikacije.stat.gov.rs/G1961/Pdf/G19614001.pdf (02. 12. 2019.).

Special-Orts-Repertorium von Dalmatien (Volkszählung vom 31. December 1890), K. K. Statistischen Central-Commission, Wien, 1894.

Stalno stanovništvo po narodnosti po popisu od 15. marta 1948. godine, Beograd, 1954, http:// publikacije.stat.gov.rs/G1948/Pdf/G19484001.pdf (02. 12. 1919.). 


\section{PRILOZI}

Prilog 1. Naselja u okruzima Herceg-Novi, Risan i Kotor navedena u popisu iz 1900.

Appendix 1. Settlements in Counties Herceg-Novi, Risan and Kotor according to the 1900 census

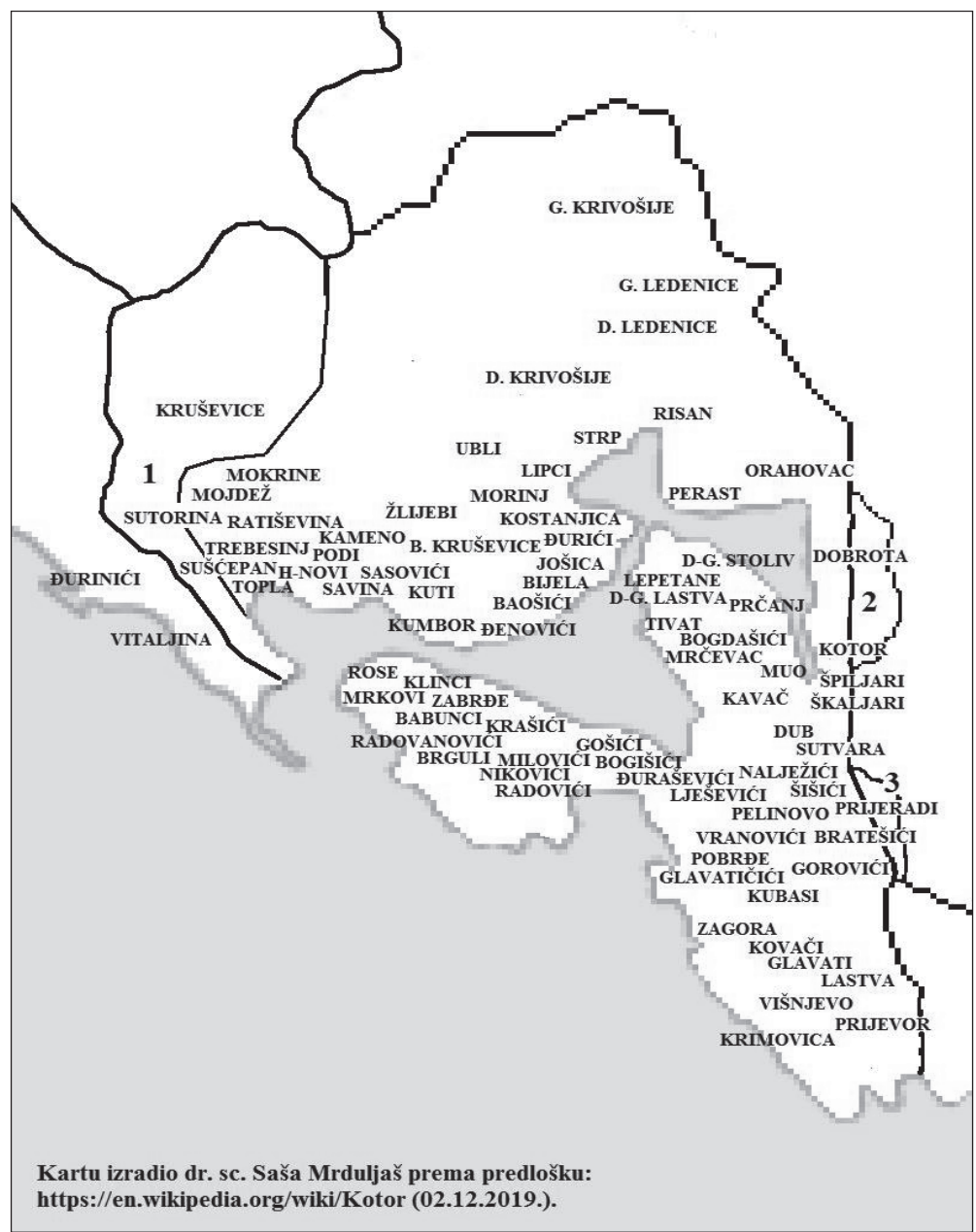

1, 2, 3 - prostori koji su tijekom trajanja Jugoslavije postali dijelom bokokotorskih upravno-teritorijalnih cjelina; 1 - Kruševice i Sutorina (u vrijeme popisa iz 1900. dio BiH); 2 - Veliki i Mali Zalazi (1900. dio Kneževine Crne Gore); 3 - Mirac, Čavori i Kolužunj (1900. dio Kneževine Crne Gore). Položaj naselja na zemljovidu približno je određen. 
Prilog 2. Naselja okruga Budva navedena u popisu iz 1900. i naselja u užoj okolici Bara

Appendix 2. Settlements in Budva County according to the 1900 census and settlements in immediate surrounding of Bara

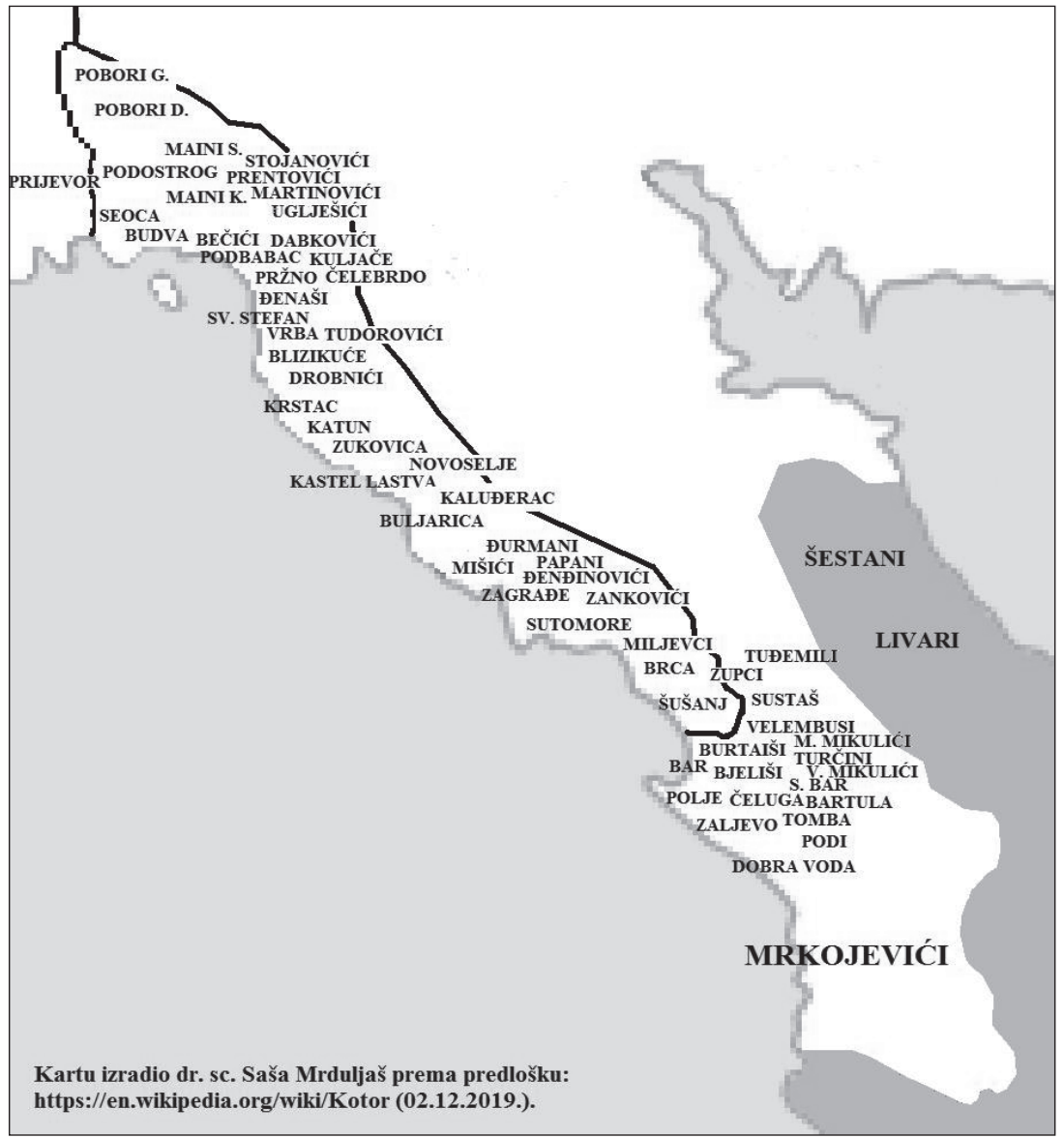

Tamnosivo - pretežito etnički albanski/albanizirani dijelovi (današnje) Crne Gore; Šestani i Livari - nekadašnje općine (1921.), a danas uglavnom raseljeni krajevi čije se katoličko stanovništvo, primarno albanskog jezika, izjašnjava i Hrvatima; Mrkojevići - muslimansko (bošnjačko) pleme i istoimena općina u vrijeme popisa iz 1921. Položaj naselja na zemljovidu približno je određen. 
Prilog 3. Podaci iz popisa 1900. o vojnicima stacioniranima u kotaru Kotor Appendix 3. 1900 census data on soldiers stationed in Kotor District

\begin{tabular}{|c|c|c|c|c|c|c|c|c|c|c|c|}
\hline & & UK & JEZ & N-J & K & $\mathbf{P}$ & D & NJ & SH & $T$ & D \\
\hline & BUDVA & 376 & 45 & 331 & 320 & 2 & 54 & 28 & 10 & 1 & 6 \\
\hline \multirow[t]{3}{*}{1} & BUDVA & & & & & & & & & & \\
\hline & Budva & 127 & 22 & 105 & 110 & 2 & 15 & 17 & 1 & - & 4 \\
\hline & Martinović & 93 & 19 & 74 & 78 & - & 15 & 7 & 9 & 1 & 2 \\
\hline \multirow[t]{2}{*}{2} & PAŠTROVIĆI & & & & & & & & & & \\
\hline & Kaštel Lastva & 73 & 3 & 70 & 58 & - & 15 & 3 & - & - & - \\
\hline \multirow[t]{3}{*}{3} & SPIČ & & & & & & & & & & \\
\hline & Sutomore & 83 & 1 & 82 & 74 & - & 9 & 1 & - & - & - \\
\hline & H-NOVI & 864 & 828 & 36 & 837 & 9 & 18 & 299 & 79 & 32 & 418 \\
\hline \multirow[t]{6}{*}{1} & H-NOVI & & & & & & & & & & \\
\hline & Herceg-Novi & 406 & 377 & 29 & 393 & 4 & 9 & 118 & 48 & 12 & 199 \\
\hline & Kumbor & 14 & 13 & 1 & 14 & - & & 1 & 5 & 7 & - \\
\hline & Podi & 234 & 230 & 4 & 229 & 1 & 4 & 126 & 2 & 3 & 99 \\
\hline & Savina & 23 & 22 & 1 & 22 & - & 1 & 10 & 4 & - & 8 \\
\hline & Topla & 112 & 111 & 1 & 109 & - & 3 & 27 & - & - & 84 \\
\hline \multirow[t]{4}{*}{2} & LUŠTICA & & & & & & & & & & \\
\hline & Klinci & 73 & 73 & 0 & 68 & 4 & 1 & 17 & 18 & 10 & 28 \\
\hline & Radovanić & 2 & 2 & 0 & 2 & - & & - & 2 & - & - \\
\hline & KOTOR & 1152 & 578 & 574 & 731 & 369 & 52 & 230 & 114 & 88 & 146 \\
\hline \multirow[t]{4}{*}{1} & KOTOR & & & & & & & & & & \\
\hline & Kotor & 747 & 311 & 436 & 424 & 281 & 42 & 160 & 47 & 28 & 76 \\
\hline & Orahovac & 46 & 45 & 1 & 44 & & 2 & 12 & & & 33 \\
\hline & Škaljari & 36 & 33 & 3 & 33 & 1 & 2 & 4 & 3 & 18 & 8 \\
\hline 2 & DOBROTA & - & - & - & - & - & - & - & - & - & - \\
\hline 3 & KRTOLE & - & - & - & - & - & - & - & - & - & - \\
\hline 4 & LASTVA & - & - & - & - & - & - & - & - & - & - \\
\hline 5 & MUO & 46 & 45 & 1 & 42 & 4 & & 16 & 17 & 1 & 11 \\
\hline 6 & PRČANJ & 120 & 12 & 108 & 32 & 82 & 6 & 5 & & 4 & 3 \\
\hline 7 & STOLIV & - & - & - & - & - & - & - & - & - & - \\
\hline 8 & TIVAT & 131 & 106 & 25 & 130 & 1 & - & 30 & 41 & 34 & 1 \\
\hline
\end{tabular}




\begin{tabular}{|c|c|c|c|c|c|c|c|c|c|c|c|}
\hline & & UK & JEZ & N-J & K & $\mathbf{P}$ & D & NJ & SH & $T$ & $\bar{D}$ \\
\hline \multicolumn{12}{|c|}{9 GRBALJ } \\
\hline & Dub & 26 & 26 & 0 & 26 & - & - & 3 & 6 & 3 & 14 \\
\hline & RISAN & 589 & 578 & 11 & 568 & 4 & 17 & 169 & 28 & 9 & 372 \\
\hline 1 & PERAST & - & - & - & - & - & - & - & - & - & - \\
\hline \multicolumn{12}{|c|}{2 RISAN } \\
\hline & Krivošije D. & 213 & 212 & 1 & 207 & 3 & 3 & 64 & 25 & 8 & 115 \\
\hline & Krivošije G. & 123 & 122 & 1 & 119 & - & 4 & 29 & - & - & 93 \\
\hline & Ledenice D. & 42 & 42 & 0 & 39 & - & 3 & 8 & - & - & 34 \\
\hline & Ledenice G. & 85 & 84 & 1 & 83 & - & 2 & 22 & - & - & 62 \\
\hline & Risan & 126 & 118 & 8 & 120 & 1 & 5 & 46 & 3 & 1 & 68 \\
\hline
\end{tabular}

\begin{tabular}{lllllllllll} 
K. KOTOR & 2981 & 2029 & 952 & 2456 & 384 & 141 & 726 & 231 & 130 & 942 \\
\hline
\end{tabular}

Izvor: Gemeindelexikon von Dalmatien, Volkszählung vom 31. Dezember 1900., Wien, 1908. 
Prilog 4. Stanovništvo Kruševica i Sutorine prema popisima Bosne i Hercegovine iz 1895. i 1910.

Appendix 4. Population of Kruševica and Sutorine according to the 1895 and 1910 census data of Bosnia and Herzegovina

\begin{tabular}{|c|c|c|c|c|c|c|c|}
\hline & & \multicolumn{3}{|c|}{ Popis 1895.a } & \multicolumn{3}{|c|}{ Popis 1910.b } \\
\hline & & UK & K & $\mathbf{P}$ & UK & K & $\mathbf{P}$ \\
\hline & KRUŠEVICA & 1168 & 6 & 1162 & 1238 & 6 & 1232 \\
\hline 1 & Bijelići & 84 & & 84 & 110 & & 110 \\
\hline 2 & Kruševica & 906 & & 906 & 969 & 6 & 963 \\
\hline 3 & Petijevići & 56 & & 56 & 53 & & 53 \\
\hline \multirow[t]{2}{*}{4} & Svrčuge & 122 & 6 & 116 & 106 & & 106 \\
\hline & SUTORINA & 931 & 17 & 913 & 1080 & 17 & 1063 \\
\hline 1 & Cjenici & 50 & & 50 & 50 & & 50 \\
\hline 2 & Lučići & 164 & 5 & 158 & 180 & 15 & 165 \\
\hline 3 & Malta & 100 & & 100 & 120 & & 120 \\
\hline 4 & Njivice & 48 & & 48 & 48 & & 48 \\
\hline 5 & Prijevor & 243 & 8 & 235 & 273 & & 273 \\
\hline 6 & Šćepuševići & 133 & & 133 & 167 & 1 & 166 \\
\hline 7 & Špulje & 55 & & 55 & 58 & & 58 \\
\hline \multirow[t]{4}{*}{8} & Žvinje & 138 & 4 & 134 & 184 & 1 & 183 \\
\hline & KRUŠEVICA & 1168 & 6 & 1162 & 1238 & 6 & 1232 \\
\hline & SUTORINA & 931 & 17 & 913 & 1080 & 17 & 1063 \\
\hline & & 2099 & 23 & 2075 & 2318 & 23 & 2295 \\
\hline
\end{tabular}

a Podaci prema: Glavni rezultati popisa... (1906), 584-587. Iz ukupnog stanovništva isključen je broj vojnika, kojih je 1895. u općini Kruševica i mjestu Kruševica bilo 42, a u općini Sutorina i mjestu Prijevor devet.

b Podaci prema: Die Ergebnisse... (1912), 382-385. Iz ukupnog stanovništva isključen je broj vojnika, kojih je 1910. u općini Kruševica i mjestu Kruševica bilo devet, a u općini Sutorina i mjestu Lučići osam. 
Prilog 5. Stanovništvo Đurinića i Vitaljine (dio općine Cavtat) prema popisu iz 1900.

Appendix 5. Population of Đurinić and Vitaljina (part of the Cavtat municipality) according to the 1900 census data

\begin{tabular}{llcccccccc}
\hline & & UK & K & P & NJ & SH & T & OST & N-J \\
\hline 1 & Đurinić & 372 & 370 & 2 & - & 372 & - & - & - \\
\hline 2 & Vitaljina & 436 & 436 & - & - & 436 & - & - & - \\
\hline & & 808 & 806 & 2 & - & 808 & - & - & - \\
\hline & & & & & & & & & \\
\hline & Vitaljina - vojnici: & 56 & 53 & 3 & 15 & 12 & 10 & 18 & 1 \\
\hline
\end{tabular}

Izvor: Gemeindelexikon von Dalmatien, Volkszählung vom 31. Dezember 1900., Wien, 1908.

\title{
Ethnic Composition of the Settlements of Boka Kotorska According to the 1900 Census
}

\author{
Saša Mrduljaš
}

\section{SUMMARY}

The existing, largely heterogeneous, religious and ethnic image of Montenegro is a result of profound transformations that have occurred on its territory over the past thousand years. The early medieval Principality of Duklja, with its backbone on contemporary Montenegrin soil, belonged to the Catholic sphere during and after the Schism of 1054. The same was true of neighbouring principalities of Travunia and Zahumlje, which were under the rule of Duklja for much of the $11^{\text {th }}$ and $12^{\text {th }}$ centuries. The metropolis of Bar played the role of the religious centre of the Principality of Duklja, which later became a kingdom. It was also the political pillar of the Vojislavljević dynasty.

At the end of the $12^{\text {th }}$ century, the former Duklja, Travunia, and Zahumlje came under the rule of Serbia, whose Orthodox church organisation acquired independent status in 1219. On the other hand, the Archbishoprics of Žiča and Peć, the latter subsequently becoming a patriarchate, were political backbones of the Serbian dynasty of Nemanjić. Since it was a period of sharp polarisation between Catholicism and Orthodoxy, the population of Duklja and Zahumlje were almost completely converted to Orthodoxy under Serbian rule. Coastal cities were a significant exception. For practical reasons, they were allowed to keep their autonomous status, including Catholicism. Under the influence of the Republic of Ragusa, Croatia, Bosnia, and the Franciscan Order, Catholicism was partially restored in the western parts of former Zahumlje and some coastal regions of Travunia. However, among the Slavic population of present-day Montenegro, Catholicism persisted only in coastal centres and in part of the settlements that gravitated towards them. 
Following the disintegration of the Serbian state, largely driven by the Ottoman invasions of the Balkans, as well as the period of change of different state authorities, the coastal areas of Montenegro came under the rule of the Venetian Republic largely during the first half of the $15^{\text {th }}$ century. Subsequent Ottoman conquests reduced the Venetian coastal possessions to tiny, mutually separated enclaves within which Catholics and Orthodox continued to co-exist mostly harmoniously. Throughout the rest of the coast, suffering further losses, this time under the Ottomans, Catholicism was maintained among a minor part of the Slavic population occupying the area surrounding Bar.

Further changes in the religious and ethnic image of Montenegro took place under the Ottoman influence. By breaking into certain border areas, Albanians established their definite domination already at the end of the Middle Ages. Furthermore, the mass Islamisation of the Albanian Catholic population encouraged similar processes in the Slavic neighbourhood. Together with neighbouring Herzegovina and northern Albania, Montenegro became a demographic source of mass migration to neighbouring, war-depopulated areas. Among other destinations, migration was directed towards the present-day Sandžak, which was continuously settled by the Montenegrin Orthodox and Muslim population. However, the most far-reaching phenomenon was the formation of sub-Lovćen Montenegro. Having expanded and acquired state capacity, its Orthodox population established a special form of selfawareness.

The ethnic differentiation of the Slavic population of Montenegro was closely linked to the religious one. Catholics were firmly oriented towards the West, which was further encouraged mainly by the prevalence of Orthodoxy but also Islam. This orientation, among other things, led to socio-cultural integration into the broader ethnic entity that shared their language and religion and became recognised as Croatian during the processes of nation formation. Since the distinct existence of Orthodoxy complied with the goals of the Serbian dynasty and state since its initiation, certain forms of Serbian proto-national awareness were conceived early among the Montenegrin Orthodox. Over time, it was challenged by the idea of Montenegrin ethnic state. This caused a break in the identity of the Montenegrin Orthodox, which continues to preclude their final national self-determination. As holders of the OttomanIslamic state concept, the Slavic Muslim population of Montenegro was historically strongly distanced from Christian fellow countrymen speaking the same language. At the same time, they identified with the rest of the Slavic Muslim population, mostly concentrated in Bosnia, which finally enabled their co-existence with the Bosniak national construct.

Given the extreme complexity of the religious and ethnic image of Montenegro and the processes that shaped it, it is expected to raise many important research questions. The attached paper focusses on one of them. Almost the entire area of intertwined relations between Slavic Catholics (Croats) and Orthodox (Serbs/ Montenegrins) was located in the part of the Montenegrin coast that defended itself against the Ottoman invasions during the Venetian rule (eastern Boka Kotorska, the town of Budva, Paštrovići), that is, the part that was liberated from the Ottomans at the turn of the $17^{\text {th }}$ century (western Boka Kotorska, the mountain range of Orjen in its hinterland, Grbalj, the immediate surroundings of Budva). During the subsequent second Austrian rule (1814-1918) the mentioned areas were parts of the Kingdom of Dalmatia and in 1878 they were joined Spič, a part of the Ottoman Catholic-Orthodox zone west of Bar. Since the centre of the whole area was located in the Bay of 
Kotor, together with Boka, it was also known under the name of Boka Kotorska in the narrow sense.

Despite centuries of interaction between Catholics and Orthodox on the ground of Boka, the first comprehensive data which may be analysed to provide a numerical insight into their religious-ethnic relations were obtained from Austrian censuses conducted from the second half of the $19^{\text {th }}$ century. However, until the end of that century, those censuses did not allow for a more accurate image of the ethnic features of Boka and (much of) its settlements. The first to make this possible is the 1900 census. Therefore, by analysing the data provided by that census, the enclosed paper attempts to specify in numerical terms the ethnic relations between Croats and Serbs/Montenegrins on the territory of Boka Kotorska, including all its settlements. More precisely, the paper deals with the territory of Kotor district, which included Boka Kotorska at the time.

According to available insights, within Kotor district, which occupied $673.79 \mathrm{~km}^{2}$, there were 34,115 inhabitants in 1900 , of which 9,565 or $28 \%$ were Croats and 23,746 or $69.6 \%$ were Serbs/Montenegrins. There were significant ethnic differences between certain parts of the said district. The mountainous regions of Orjen, inhabited by the Krivošije tribe, were almost completely homogeneous. The area of approximately $200 \mathrm{~km}^{2}$ was settled by 2,235 inhabitants, of which 42 or $1.9 \%$ were Croats, mostly immigrants, while 2,187 or $97.9 \%$ were Serbs/Montenegrins. The situation was similar in the coastal area between Kotor and eastern Spič (Grbalj municipality /without Lješević/, Budva and its immediate surroundings, Paštrovići and three homogeneous Serbian/Montenegrin settlements in the western part of Spič municipality). The area of approximately $210 \mathrm{~km}^{2}$ was occupied by 9,427 inhabitants, of which 368 or $3.9 \%$ were Croats and 9,012 or $95.6 \%$ were Serbs/Montenegrins. Within that area, Croats lived as indigenous population only in the town of Budva (301) and as a small minority in Kastel Lastva, which was subsequently renamed Petrovac na Moru (21).

Boka Kotorska was ethnically heterogeneous in the narrow sense. This applied to the coastal areas of the bay as well as those that were not by located the sea but gravitated towards the Boka coast. The narrow area of Boka occupying approximately 230 $\mathrm{km}^{2}$ was inhabited by 21,473 people, of which 8,332 or $38.8 \%$ were Croats and 12,390 or $57.7 \%$ Serbs/Montenegrins. There was a noticeable difference between the western part of Boka, which had once belonged to the Ottoman Empire, and the eastern part, which used to be under the Venetian Republic. In 1900 the former Ottoman Boka was inhabited by 9,879 people, of which 1,190 or $12.1 \%$ were Croats while 8,438 or $85.4 \%$ were Serbs/Montenegrins. The area of former Venetian Boka had 11,594 inhabitants, of whom 7,142 or $61.6 \%$ were Croats and 3,952 or 34.1\% were Serbs/Montenegrins.

This formerly Venetian part also consisted of two separate, more or less homogeneous, ethnic entities. One was predominantly Croatian, with 9,458 inhabitants, of whom 7,023 or $74.3 \%$ were Croats and 1,935 or $20.5 \%$ were Serbs/Montenegrins (many settlements on the Vrmac peninsula/mountain, a part of the sub-Lovćen coastal area, and the towns of Perast, Strp-Lipci, Kostanjica, Đurići, Krašići). The predominantly Serbian/Montenegrin majority counted 2,136 inhabitants; 119 or 5.6\% of Croats and 2,017 or $94.4 \%$ of Serbs/Montenegrins (Luštica without Krašići, Krtole, Lješevići)

Particularly interesting was eastern Spič, occupied by 980 inhabitants, of which 823 or $84 \%$ were Croats and 157 or $16 \%$ were Serbs/Montenegrins. Eastern Spič should 
essentially be considered in the context of the remaining Bar coast, which belonged to the Principality of Montenegro at the time. It should be noted that this Montenegrin part of the Bar coast was distinguished not only by the presence of the Croatian and Montenegrin population but also by a strong representation of the Bosniak community. As already pointed out, although relatively homogeneous ethnic entities existed within the Kotor district, including the mentioned entity between Kotor and eastern Spič, precisely its ethnic features, together with those of the immediate surroundings of Bar, allowed the total coastal area between Herceg-Novi and Bar to be perceived as a space of exchange between Croats and Serbs/Montenegrins.

The area of Boka Kotorska is one in a series of localities where a heterogeneous ethnic image was historically formed. Such regions are particularly interesting to researchers since the complex ethnic image could only emerge from complex political and social processes. The paper aimed at reconstructing that image according to the results available from the 1900 census. The study focussed on data relating to distinctiveness that providing a basic insight into its features. Such phenomena certainly need to be addressed, as well as the processes they caused. They primarily fostered a special social climate in which one had to pay attention to differences and know how to co-exist with them. The entire Montenegrin coast has extensive experience in this regard.

Many problems arose from this experience. Some of them were self-imposed or constituted reflections from the wider social scene or were imported by the immigration of individuals with different cultural and political sensibilities. The fact remains that, even during the worst temptations experienced in the area, despite all the differences and regardless of religion and variable historical conditions, the population of Boka has preserved the ability to co-exist. Although the "set of circumstances" played a role in this, such development was not undermined by the distinctive flexibility of the Montenegrin coastal population, regardless of religion. It manifested itself through centuries of mutual interaction and multiple social ties, including familial ones. This positive heritage and the culture that produced it should also be attributed due importance. Finally, the meaning of Catholicism and Orthodoxy was perhaps best manifested exactly at that level.

KEY WORDS: Boka Kotorska, census, Catholicism, Orthodoxy, Croats, Serbs, Montenegrins 